UNIVERSIDADE DE SÃO PAULO

FACULDADE DE ECONOMIA, ADMINISTRAÇÃO E CONTABILIDADE DEPARTAMENTO DE ADMINISTRAÇÃO

PROGRAMA DE PÓS-GRADUAÇÃO EM ADMINISTRAÇÃO

PERCEPÇÃO DE RISCO E ESCOLHA DOS CONTRATOS NAS TRANSAÇÕES DE VENDA DO CAFÉ

Renan Grassi Franco de Menezes

Orientador: Prof. Dr. Decio Zylbersztajn

SÃO PAULO 
Prof. Dr. João Grandino Rodas

Reitor da Universidade de São Paulo

Prof. Dr. Reinaldo Guerreiro

Diretor da Faculdade de Economia, Administração e Contabilidade

Prof. Dr. Adalberto Américo Fischmann

Chefe do Departamento de Administração

Prof. Dr. Lindolfo Galvão de Albuquerque

Coordenador do Programa de Pós-Graduação em Administração 
RENAN GRASSI FRANCO DE MENEZES

\title{
PERCEPÇÃO DE RISCO E ESCOLHA DOS CONTRATOS NAS TRANSAÇÕES DE VENDA DO CAFÉ
}

\author{
Dissertação apresentada ao Programa de Pós- \\ Graduação em Administração da Faculdade de \\ Economia, Administração e Contabilidade da \\ Universidade de São Paulo, para obtenção do título de \\ Mestre em Ciências.
}

Orientador: Prof. Dr. Decio Zylbersztajn

\author{
Versão Corrigida \\ (versão original disponível na unidade que aloja o Programa)
}

SÃO PAULO 


\section{FICHA CATALOGRÁFICA}

Elaborada pela Seção de Processamento Técnico do SBD/FEA/USP

Menezes, Renan Grassi Franco de

Percepçẫo de risco e escolha dos contratos nas transaçốes de venda do café / Renan Grassi Franco de Menezes. - São Paulo, 2012.

$103 \mathrm{p}$.

Dissertaçẫo (Mestrado) - Universidade de Sẫo Paulo, 2012.

Orientador: Decio Zylbersztajn.

1. Economia institucional 2. Cafeicultura 3. Avaliaçẫo de risco I. Universidade de Sẫo Paulo. Faculdade de Economia, Administraçã̃o e Contabilidade II. Título.

CDD -330 
Dedico este trabalho à minha família. 
Agradeço a Deus pelas inúmeras bênçãos, pela saúde e força ao longo deste curso.

Agradeço ao Prof. Dr. Decio Zylbersztajn pela orientação, paciência e tempo despendido.

Agradeço a minha família por ser meu alicerce e a origem de qualquer qualidade que possuo.

Sou grato pelo meu pai, meu herói.

Sou grato pela minha querida irmã, minha amiga.

Sou grato pela minha amada mãe, um anjo enviado por Deus.

Sou grato pelo companheirismo da Larissa, minha namorada incondicional. 


\section{RESUMO}

Existem evidências de que os produtores de café preferem transacionar via mercado spot ao invés de atuar em mercados de entrega futura ou realizar contratos de longo prazo com a indústria. Se o estabelecimento de contratos permite a redução do risco, quais fatores, associados a estas formas de transação, estariam influenciando a decisão dos cafeicultores? Este trabalho busca relacionar a determinação da forma de governança da transação de venda do café com a maneira como o cafeicultor percebe o risco. Sob a perspectiva da geração da renda, a preferência por relações spot, portanto, de curta duração é justificável? Como o tomador da decisão incorpora sua visão do risco para fazer sua escolha? Para esclarecer tais questões, primeiramente, são conduzidas entrevistas com produtores, visando identificar o perfil dos cafeicultores e entender como, mesmo que implicitamente, eles incorporam a gestão de rico em suas escolhas contratuais. Em seguida, este estudo elabora um modelo de simulação da renda dos produtores utilizando dois cenários, o ocorrido (cenário real) e um cenário com a adoção de contratos que limitem a margem de variação dos preços.

\section{Palavras-chave: desenho contratual, fatores de risco, cafeicultura, arranjos institucionais, formas de governança.}




\begin{abstract}
There are evidences pointing that coffee producers rather prefer transact their product through spot market than by future contracts or by long-term contracts with the industry. If the establishment of those contracts allows risk reduction and mitigation, what factors associated with these transaction forms are influencing the producers' decisions? This study seeks to unite the governance form choice of the coffee selling transaction with the risk observance by the producers. Under the perspective of income generation, the preference for spot transactions is justified? How the decision maker aggregates his risk vision in order to make such choice? To answer those questions, first, an income simulation model is derived, using two scenarios, one using real spot price and another one with hypothetical contracts that diminishes the price fluctuation. Following that, interviews with a few producers take place, in order to understand how they, even if in implicit way, incorporate a risk managing notion to their activity.
\end{abstract}

Keywords: contract design, risk factors, coffee production, governance forms. 


\section{SUMÁRIO}

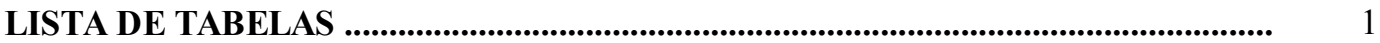

LISTA DE GRÁFICOS........................................................................................... 2

LISTA DE FIGURAS.................................................................................................................... 3

1. INTRODUÇÃ O.............................................................................................. 5

1.1 Problema de pesquisa e objetivos........................................................................ 5

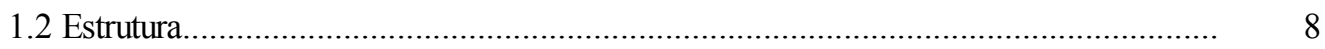

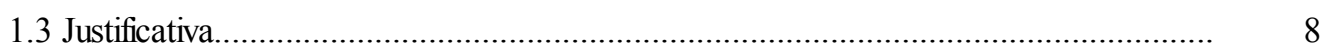

2. ECONOMIA DOS CONTRATOS E O RISCO.................................................. 15

2.1 Formas de Governança.......................................................................................... 15

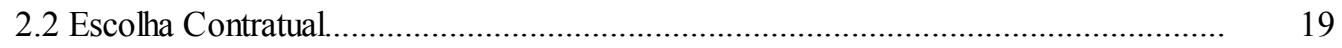

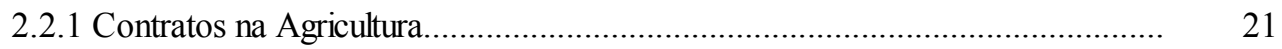

2.2.2 Outros modelos de desenho contratual................................................................ 24

2.3 Alocação do Risco.......................................................................................... 25

2.4 O Sistema Agroindustrial do Café............................................................................ $\quad 30$

2.4.1 A transação de venda do café........................................................................ 35

3. HIPÓTESES DE PESQUISA............................................................................................ 39

4. MÉTODO....................................................................................................... 45

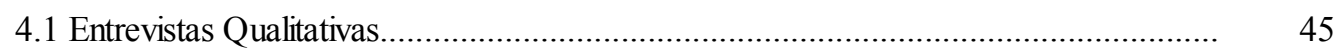

4.1.1 Região de interesse: Sul de Minas Gerais........................................................... 46

4.1.2 Visão geral dos procedimentos de campo.......................................................... 47

4.1.3 Procedimentos iniciais................................................................................. 47

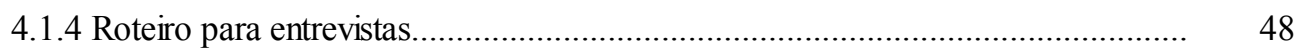

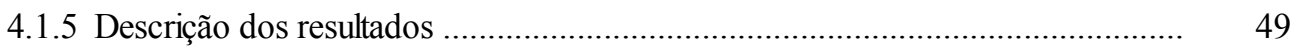

4.2 Modelo de Simulação.............................................................................................. 49

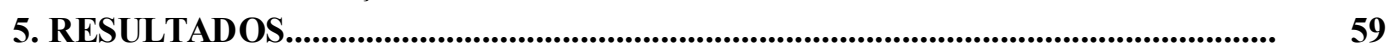

5.1 Entrevistas qualitativas....................................................................................... 59

5.1.1 Fazenda das Almas.................................................................................. 59

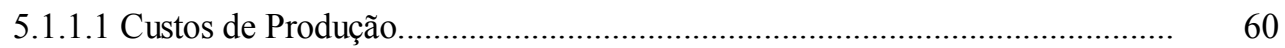

5.1.1.2 Condições do clima.................................................................................... 60

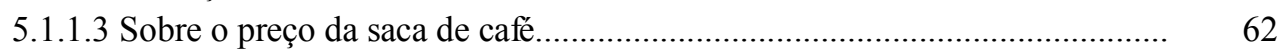

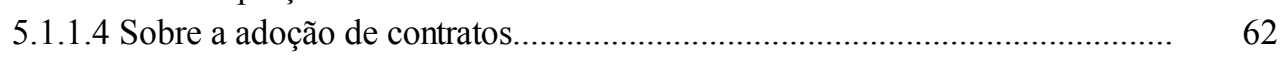

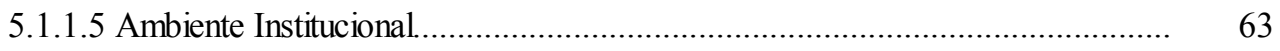

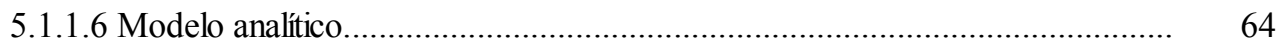




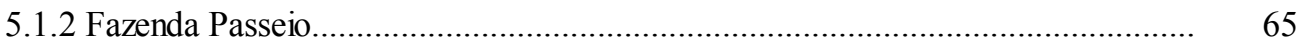

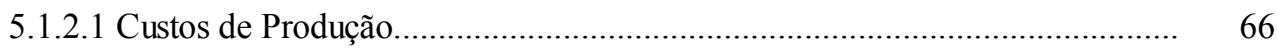

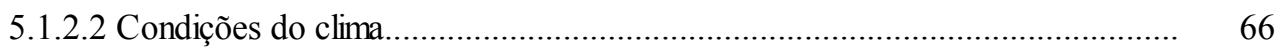

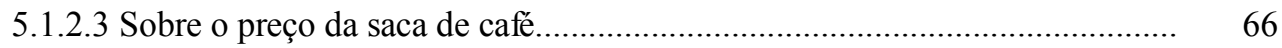

5.1.2.4 Sobre a adoção de contratos e o ambiente institucional..................................... 67

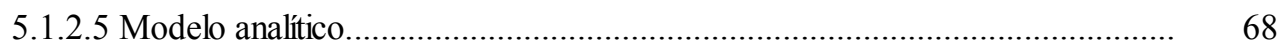

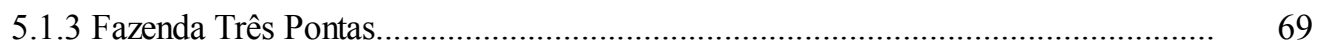

5.1.3.1 Custos de Produção.................................................................................... 70

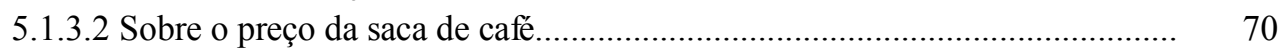

5.1.3.3 Condições do clima...................................................................................... 71

5.1.3.4 Sobre a adoção de contratos e o ambiente institucional.................................... 71

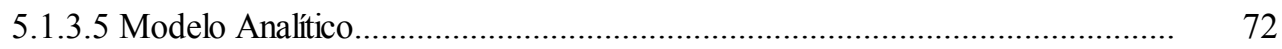

5.2 Modelo de Simulação............................................................................................. 73

5.2.1 Período entre 1996 e 2001 - Ciclo de baixa........................................................ 76

5.2.2 Período entre 2002 e 2011 - Ciclo de alta........................................................... 77

5.2.3 Período entre 1996 e 2011 - Ciclos de baixa e alta.............................................. 77

5.3 Variação do prêmio de risco............................................................................... 79

5.4 Variação do parâmetro de variabilidade..................................................................... 80

5.5 Variação do desvio-padrão como elemento contratual.................................................... 81

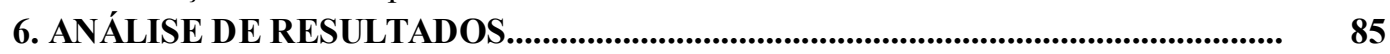

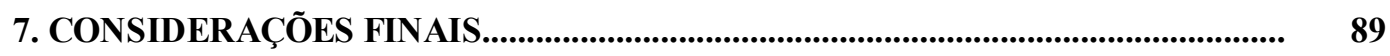

REFERÊNCIAS BIBLIOGRÁFICAS..................................................................... 91 


\section{LISTA DE TABELAS}

Tabela 1 - Construção da FDT: Parâmetros

Tabela 2 - Resultados da Simulação

Tabela 3 - Renda Simulada para o Período entre 1996 - 2001

Tabela 4 - Renda Simulada para o Período entre 2002 - 2011

Tabela 5 - Renda Simulada para o Período entre 1996 - 2011

Tabela 6 - Comparação entre o Ciclo de Alta e o período completo

Tabela 7 - Ciclo de Alta - Aversão ao risco

Tabela 8 - Ciclo de Alta - Propensão ao risco

Tabela 9 - Ciclo de Baixa - Aversão ao risco

Tabela 10 - Ciclo de Baixa - Propensão ao risco

Tabela 11 - Ciclo de Baixa - Alteração do parâmetro de variabilidade: 35\%

Tabela 12 - Ciclo de Alta - Alteração do parâmetro de variabilidade: 35\%

Tabela 13 - Alteração do desvio-padrão para 0,25 desvios-padrão (Ciclo de Baixa)

Tabela 14 - Alteração do desvio-padrão para 2 desvios-padrão (Ciclo de Baixa)

Tabela 15 - Alteração do desvio-padrão para 0,25 desvios-padrão (Ciclo de Alta)

Tabela 16 - Alteração do desvio-padrão para 2 desvios-padrão (Ciclo de Alta) 


\section{LISTA DE GRÁFICOS}

Gráfico 1 - Evolução Histórica: Consumo e Exportação do Café

Gráfico 2 - Curvas de Indiferença entre preço e risco

Gráfico 3 - Formas de Governança e especificidade de ativos

Gráfico 4 - Propensão ao Risco: Visão Neoclássica

Gráfico 5 - Indicador Histórico Internacional - Preço Médio Anual

Gráfico 6 - Função de densidade e probabilidade triangular

Gráfico 7 - Função de densidade de probabilidade triangular

Gráfico 8 - Funções Densidades de Probabilidades: Preços de Café

Gráfico 9 - Funções Densidades de Probabilidades: Preços de Café 


\section{LISTA DE FIGURAS}

Figura 1 - Modelo analítico: A decisão do cafeicultor

Figura 2 - Esquema contratual simplificado

Figura 3 - O Sistema Agroindustrial do Café

Figura 4 - Subsistemas Estritamente Coordenados

Figura 5 - A transação de interesse

Figura 6 - Trade-off do cafeicultor

Figura 7 - A decisão do produtor implica em geração de renda

Figura 8 - Influência dos fatores de risco na decisão

Figura 9 - Visão geral das entrevistas qualitativas

Figura 10 - Funções Densidades de Probabilidades: Regra para geração da renda 


\section{INTRODUÇÃO}

\subsection{Problema de pesquisa e objetivos}

Os produtores de café têm preferência pelo uso do mercado spot para escoar sua produção em detrimento de contratos de entrega futura com exportadores e indústrias ou o próprio mercado futuro. A partir de contato com os atores desse mercado, como traders e membros de cooperativas, esta observação sobre o comportamento dos cafeicultores encontra evidências iniciais. Foram realizados contatos exploratórios com traders e representantes de cooperativas agrícolas da região do sul de Minas Gerais entre agosto e setembro de 2011. Por que os contratos são preteridos por esses produtores?

Sob o ponto de vista daqueles que negociam o café, os traders, os produtores podem ser separados conforme seu tamanho. No caso dos pequenos, a preferência pelo mercado à vista justifica-se pela necessidade de geração de fluxo de caixa. Não existe espaço para estratégias para tentar diversificação quanto à escolha transacional. Produtores de maior porte apresentam um apetite maior para se engajar em formas alternativas de escoamento, mas ainda preferem atuar no mercado à vista. Além disso, essa tendência se alimenta de um mercado interno brasileiro com demanda estável.

Segundo representantes de cooperativas agrícolas, a falta de esclarecimentos e informações sobre as formas alternativas de transação dificultam sua utilização e distancia o produtor de desfrutar suas vantagens potenciais.

Os contratos futuros de café, por exemplo, podem ser liquidados a qualquer tempo antes de seu vencimento, tanto por meio da operação de natureza oposta à originalmente efetuada ou pela própria entrega física da mercadoria. $\mathrm{O}$ vendedor que desejar entregar café via Bolsa deve enviar a mercadoria para armazém credenciado pela Bolsa. Ademais, é consenso que, dentre os produtos agropecuários oferecidos pela $B M \& F, o$ contrato futuro de café (arábica) é aquele com liquidez mais satisfatória.

Nos mercados futuros, embora o objeto de negociação sejam quantidades de determinado produto agropecuário, não existe necessariamente a intenção de 
comercializar esses produtos na forma física, isto é, trata-se de um mercado de intenções, no qual, na realidade, são negociados os preços futuros da mercadoria. $\mathrm{O}$ risco pode ser transferido, ou seja, negociado.

Neste sentido, Lazzarini (1998) ao analisar o mercado futuro de Boi Gordo na BM\&F, notou que o volume de negociação de novos contratos futuros era baixo, com um grau de sucesso de novos contratos variou de 25 a 32\%. A geração de novos contratos e o estabelecimento das bases para seu sucesso depende da capacidade das Bolsa em perceber elementos que conduzam a um maior nível de negociação, dentre eles o desenho dos contratos.

Os contratos futuros não são as únicas formas transacionais além do mercado spot. $\mathrm{O}$ produtor poderá negociar seu café realizando:

a) Contratos no mercado a termo: acordos de compra ou venda em determinada data futura por preços previamente estabelecidos, cuja liquidação financeira ou entrega física do ativo acontece somente no vencimento.

b) Contratos multiperíodos com traders: podem assumir caráter especulativo, sendo estabelecidos em diferentes horizontes de tempo. Os produtores que o utilizam preocupam-se mais com a realização de hedge de preços.

c) Contratos com a indústria: acordos sob os quais são exigidos diversos atributos para o produto final, de forma a garantir certo patamar de qualidade do café.

É interessante destacar que, na escolha da forma de transação do café, o produtor dificilmente recorre individualmente aos contratos. Quando o faz, é por meio da iniciativa da cooperativa da qual é membro.

Williamson (1985) enumera três dimensões para as transações, que guardam relação com a escolha das suas respectivas formas de governança. Este estudo mantém o foco na dimensão da incerteza, sob a sua forma mensurável, ou seja, o risco. Como ele é alocado na realização dessa escolha? Se o estabelecimento dos contratos pressupõe a diluição do risco, é relevante entender o porquê da escolha pelo mercado spot em detrimento da realização de outros tipos de contratos, seja no mercado futuro, seja de entrega futura com exportadores. Dada a percepção de risco pelos produtores e supondo que a influência de fatores de risco contribui de forma significativa para a escolha por 
transações via mercado spot, é instigante relacioná-los com a decisão do cafeicultor. Em suma, esses elementos permeiam as duas questões centrais do presente trabalho:

\section{a) Sob a perspectiva da geração da renda, a escolha pelo mercado spot para escoar a produção de café representa alternativa superior aos contratos?}

\section{b) Quais são os fatores de risco percebidos pelos produtores de café em contratos alternativos ao mercado spot?}

Assim, o objetivo central deste estudo é explicar a escolha dos cafeicultores sob a ótica de sua percepção de risco diante das alternativas para transacionar o café. Para alcançar esse objetivo central, propõem-se alguns objetivos específicos que seguem:

- Comparar a renda advinda de negociações no mercado spot com aquela derivada de outras formas de governança, como os contratos.

- Elaborar um contrato hipotético que limite a variação dos preços e compará-lo com o mercado spot.

- Identificar como a percepção de risco se distingue entre o cafeicultor cooperado e não cooperado dado que a escolha da forma de negociação não é feita pelo produtor individual, mas sim pela cooperativa.

- Verificar quais são os empecilhos percebidos pelos agricultores para a utilização do contrato com travamento de preço do café. 


\subsection{Estrutura}

Este trabalho está estruturado em sete partes. Posto o problema nesta seção, será feito o levantamento do arcabouço teórico tangente à discussão: i) sobre desenhos contratuais e arranjos institucionais; ii) sobre a economia dos contratos na cafeicultura. A partir disso, na terceira parte, será possível elaborar as hipóteses de pesquisa a serem testadas.

Na quarta parte será explicitado o método, constituído: i) primeiramente pela elaboração de entrevistas qualitativas e ii) pela construção de modelos de simulação, com foco no comportamento dos preços do café e na geração da renda para o produtor.

$\mathrm{Na}$ quinta e sexta partes, serão respectivamente apresentados e discutidos os resultados advindos do método proposto. Finalmente, serão feitas considerações para relacionar os resultados obtidos pelo método com o problema proposto.

\subsection{Justificativa}

A relevância das indagações propostas está no fato de contrapor o pressuposto teórico de mitigação do risco via contratos e o comportamento real observado dos cafeicultores. A contribuição esperada deste trabalho é testar a aderência de pressupostos teóricos das transações via contrato ante o que de fato se passa no mundo dos produtores de café. Para esse mercado, os níveis de risco estariam fora do escopo de controle da elaboração de um contrato?

A relevância do café para a economia brasileira é conhecida. O gráfico a seguir mostra como o aumento das exportações do café anda em linha com o aumento da produção, enquanto o consumo, medido pela quantidade de sacas ou pelo consumo médio por habitante, apresenta um comportamento mais estável, ainda que mostre uma tendência positiva de crescimento. Os "dentes" vistos na figura mostram que o excedente de produção é exportado imediatamente. 


\section{Gráfico 1 - Evolução Histórica: Consumo e Exportação do Café}

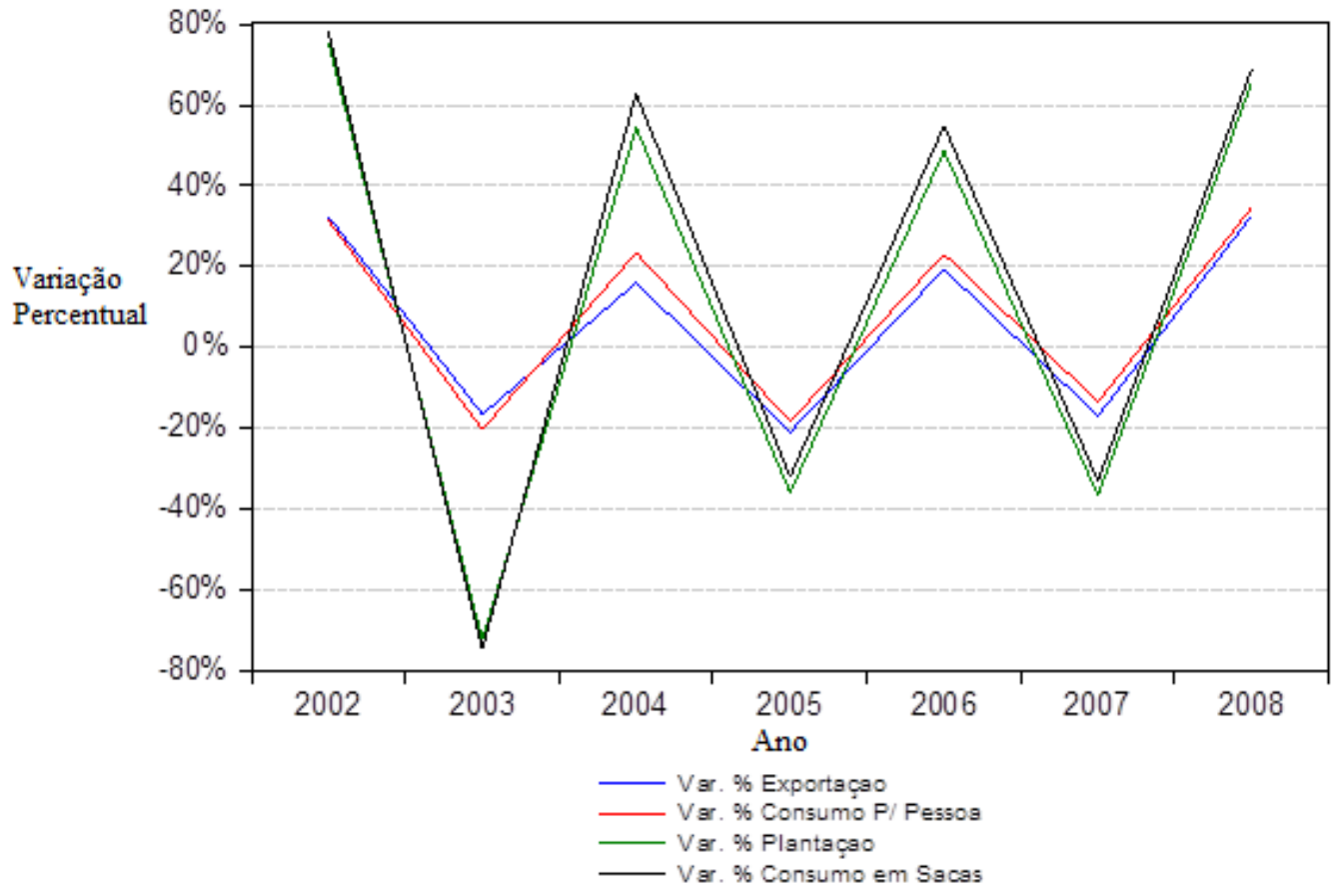

Fonte: Conselho dos Exportadores de Café (CECAFE)

Sabe-se também, conforme anuário estatístico do Ministério da Agricultura, que entre 2009 e 2010 o consumo interno brasileiro de café (em milhões de sacas) aumentou em $4 \%$ e a quantidade de sacas destinadas à exportação em 9,8\%. Segundo dados do $\mathrm{BM} \& \mathrm{~F}$, o número de contratos de mercado futuro de café caiu em aproximadamente $10 \%$.

O problema introduzido pode ser estudado sob a ótica da escolha contratual em situação de ausência de poder de monopólio (monopsônio), ou seja, o produtor é livre para escolher o contrato que melhor lhe cabe e vender para qualquer comprador. Essa questão pode ser representada pela figura a seguir, que mostra a decisão de como transacionar o café num dado instante $t$ : 
Figura 1 - Modelo analítico: A decisão do cafeicultor

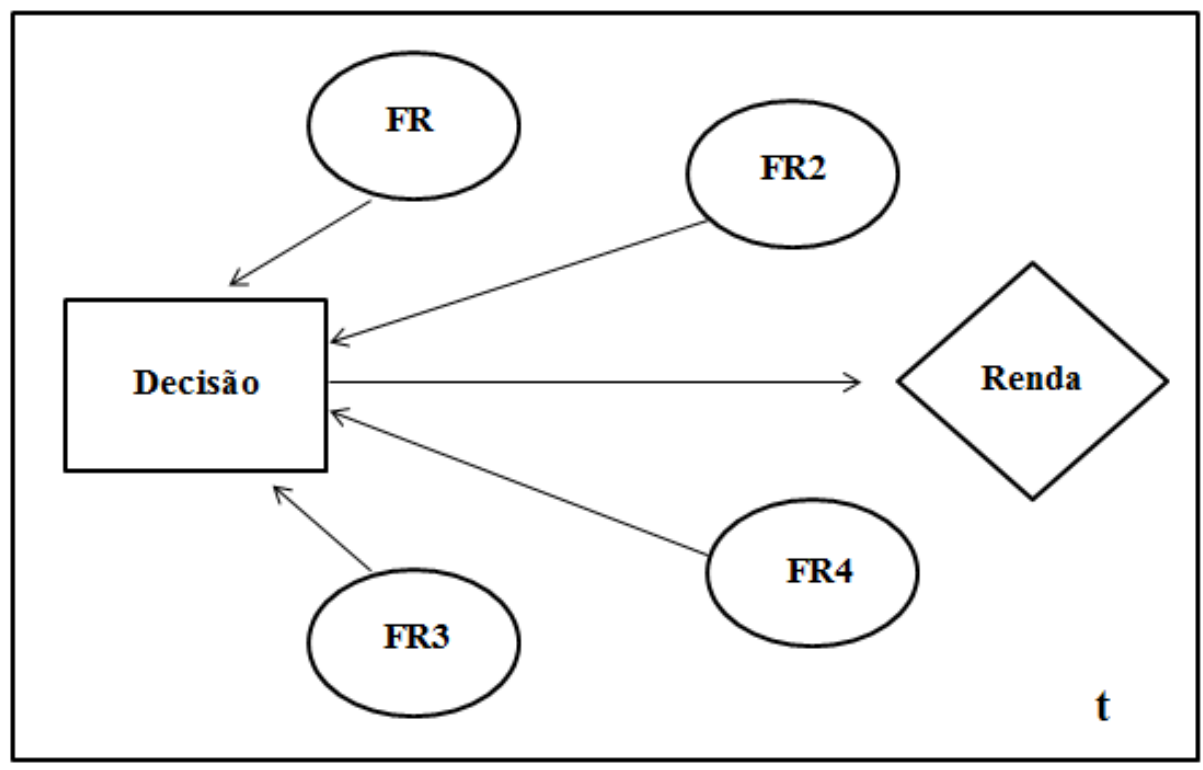

Fonte: $\mathrm{O}$ autor

A decisão é definida como aquela na qual o produtor estabelece um compromisso de entrega de uma determinada quantidade de produto, com características conhecidas e observáveis, para uma contraparte compradora, em determinado instante do tempo a um preço acordado. Com a realização dessa transação, o produtor obterá uma renda. Sendo o café um produto estocável, a partir do momento de sua colheita é possível transacioná-lo totalmente ou estocá-lo, de forma a negociar apenas uma fração. A unidade de tempo transacional $t$ denota o momento de entrega da maior fração correspondente a uma safra.

Tais decisões estão inseridas num ambiente cercado por fatores de risco ( $F R 1, F R 2$ no diagrama) e mediante a percepção e mensuração do risco e retorno supõe-se que as mesmas são tomadas. O produtor escolherá uma forma de transacionar seu produto, alcançando determinado nível de renda. Nesse sentido, é pertinente identificar qual a melhor forma transacional sob o ponto de vista da geração de renda e como os fatores de risco influenciam a decisão.

Um fator a ser considerado pelo produtor, capaz de alterar o resultado futuro de sua atividade, é o chamado risco de mercado, associado aos movimentos de volatilidade dos preços, explica Jorion (2003). Essa variável é tradicionalmente considerada em estudos 
empíricos, haja vista que as contrapartes envolvidas na transação desejam se proteger de movimentos adversos do preço do café que negociam.

Segundo Correa (2001), os participantes da cadeia produtiva de café se deparam com os riscos de variação de preço da mercadoria. O produtor, considerando o momento futuro da comercialização do café, depara-se com a incerteza de preço, pois poderá sofrer prejuízos econômicos, caso o preço venha a se depreciar ou perder oportunidade de renda caso o preço seja apreciado. A indústria torrefadora incorre no risco de o preço (da matéria-prima) elevar-se muito e não conseguir repassar seu custo para o faturamento. $\mathrm{O}$ exportador, caso feche o preço de exportação no ato da aquisição no mercado interno, pode ter sua margem de lucro comprometida. Nesse sentido, os mercados de contratos futuros podem constituir um caminho para a mitigação da incerteza de preço.

Os contratos futuros de café negociados na BM\&F e na New York Board of Trade (Nybot) apresentam diferencial de preços importante, que viabiliza o que se denomina arbitragem dos mercados. Em determinados momentos, se o preço no Brasil se situar muito abaixo daquele praticado nos Estados Unidos ou vice-versa, os participantes procurarão arbitrar essas diferenças, comprando onde o preço estiver mais baixo e vendendo mais caro em outro mercado. Essa estratégia tende a prevalecer enquanto há diferenças entre os preços nos dois mercados, mas a própria atuação dos "arbitradores" tende a corrigir tais diferenças. Mesmo assim, raramente o produtor agrícola é um dos participantes destes mercados.

Uma decisão é definida como "arriscada" quando implica resultados incertos ao seu tomador, considerando-se seu grau de aversão ao risco. A rigor, torna-se impossível dissociar "risco" e "decisão". Uma decisão eficiente não implicará sempre no melhor resultado, mas sim num resultado consistente com a percepção do risco, detectados no momento da escolha.

Os produtores alocam sua propensão ao risco de acordo com o preço que aceitam receber pela sua mercadoria. Desta forma, conforme Varian (2003), os agentes poderão ser propensos, neutros ou avessos ao risco. O gráfico a seguir ilustra estas segregações. 


\section{Gráfico 2 - Curvas de Indiferença entre preço e risco}

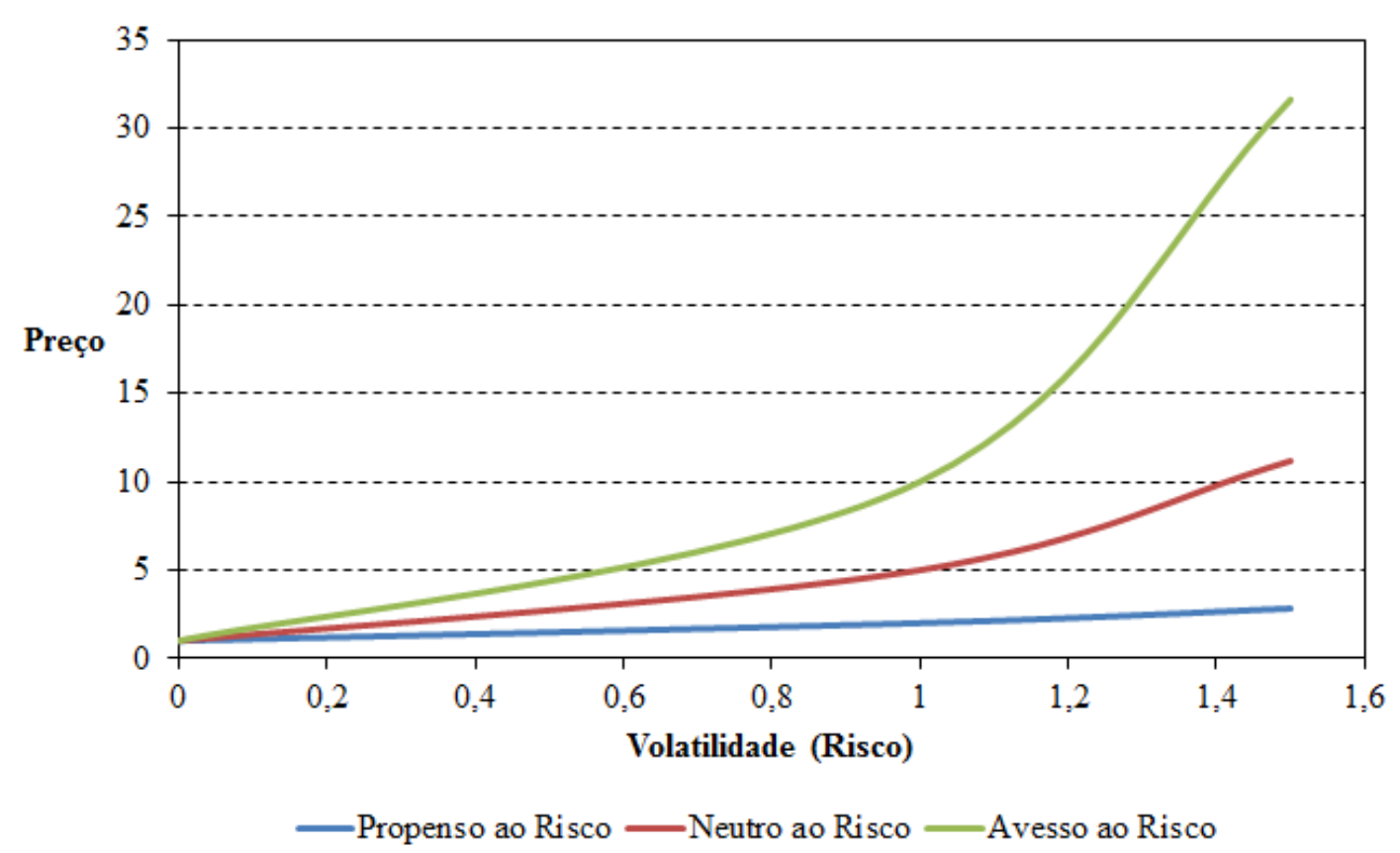

Quanto mais propenso ao risco um indivíduo é, mais plana é sua curva de indiferença, a compensação no nível de preço não é tão acentuada. Para o produtor avesso ao risco para cada movimento ao longo do eixo que mede a volatilidade, o nível de preço deverá aumentar mais que proporcionalmente, compensando a exposição ao risco. Entre as duas curvas, o agente mais próximo da indiferença perfeita, ele troca risco e preço na mesma proporção.

O produtor poderá, por exemplo, atuar no mercado capaz de oferecer maior preço. Produzirá, dessa forma, uma saca destinada ao mercado spot ou produzirá e venderá um café com uma maior especificação técnica, destinado ao processamento industrial. Assim sendo, pode não ser desejável estabelecer contratos, ao parecer mais rentável, no curto prazo, atuar dentro de um mercado mais apreciado.

Busca-se, aqui, a investigação das diferenças de geração de renda entre as formas transacionais. Dado que o cafeicultor escolheu uma forma de escoar sua produção, no longo prazo, as formas de negociação preteridas proveriam um retorno acumulado semelhante? 
Ou seja, é necessário comprovar, sob esse aspecto, quão consistente é a escolha dos produtores pelo mercado spot. Espera-se encontrar que a variabilidade da renda de distintas formas de transação apresente um comportamento semelhante. E assim também concluir que os produtores conseguiriam retornos tão bons nas diferentes formas transacionais.

De acordo com Motta (2008) é possível identificar a existência de outros tipos de risco aos quais os produtores ou empresas agropecuárias estão sujeitos. O presente trabalho mantém o foco nos fatores de risco climático, macroeconômico e institucional.

Conforme Jorion (2003), o risco intrínseco de uma atividade econômica ligada ao uso da terra, associa-se às variações climáticas. Embora o café possa ser produzido em uma extensa área geográfica, abrangendo uma ampla variação de clima e solo, a sua produção econômica, entretanto, se restringe a uma área menor, dentro daqueles limites, onde os fatores ecológicos são mais favoráveis e até certo ponto previsíveis. Portanto, a incerteza associada às variações da temperatura e também da incidência de geadas influi diretamente na definição da relação contratual.

Finalmente o ambiente institucional e macroeconômico também são elementos capazes de gerar incerteza para os produtores sendo influenciadores das decisões a respeito de sua atuação no mercado cafeeiro. À medida que muda o ambiente institucional altera-se o ambiente competitivo, e todos os agentes econômicos envolvidos no processo produtivo do agronegócio são afetados.

Portanto, os vetores associados ao ambiente institucional (a legislação, as políticas públicas de financiamento e as variáveis macroeconômicas) afetam as variáveis econômicas e a obtenção da renda no sistema agroindustrial do café. Este estudo relacionará estes elementos com a escolha contratual e a alocação de risco do cafeicultor. O próximo capítulo trará os aspectos teóricos pertinentes a ambos elementos. 


\section{ECONOMIA DOS CONTRATOS E O RISCO}

\subsection{Formas de Governança}

As questões de pesquisa deste trabalho estão embasadas nos conceitos da Nova Economia Institucional (NEI), que, conforme Menard (2004), contempla dois aspectos. O primeiro lida com a natureza das instituições e seu impacto no desempenho das atividades econômicas. O segundo é voltado para a natureza da firma e para a coordenação dos recursos com vistas à minimização de custos.

A Economia Institucional difere da Teoria Neoclássica que apregoa que os sistemas econômicos funcionam apenas por intermédio do sistema de preços e a firma seria a materialização da função de produção. Coase (1937) introduziu uma quebra nesse paradigma ao propor que o sistema de preços implica custos para o funcionamento dos mercados.

Fora dos limites da firma, o movimento de preços direciona a produção, mas dentro deles, as transações necessitam de coordenação. Uma firma poderá, portanto, apresentar um mix de escolhas entre comprar ou fabricar internamente. Duas questões cruciais surgem. Por que as organizações existem? Como elas se organizam internamente?

A explicação para as diferentes formas de coordenação de um processo produtivo está, portanto, na existência dos custos de transação. Quando os custos de transacionar no mercado são maiores que os custos de internalizar a produção, a coordenação é feita de modo mais eficiente dentro da firma. A recíproca é verdadeira também. Williamson (1985) aprofunda essa ideia ao relacionar os arranjos institucionais com uma visão minimizadora dos custos de transação, sendo esse, o ponto de partida para os estudos das organizações.

A chamada Economia dos Custos de Transação (ECT) examina a Economia das Organizações sob o ponto de vista da contratação. Para enxergar os problemas advindos do ato de se contratar, é necessário identificar quais são as dimensões de uma transação. 
Primeiramente, é necessário apontar os pressupostos fundamentais da ECT, entre os quais os de natureza comportamental. A racionalidade contrasta com a racionalidade plena da teoria Neoclássica, ao assumir que os agentes embora possuam intenções racionais, estão restritos à sua própria condição cognitiva, ou seja, são caracterizados pela racionalidade limitada, conceito esse que já vinha de Simon. Decorre daí que os contratos sempre serão incompletos, uma vez que se torna impossível prever todos os estados contingentes ao futuro (AZEVEDO, 1996).

Portanto, esse pressuposto refere-se aos limites na capacidade de cada indivíduo de processar e lidar com a complexidade, ou seja, as partes têm dificuldade em enumerar cada contingência que possa surgir durante uma transação, gerando dificuldade na elaboração do contrato (BESANKO et al., 2006).

Do mesmo modo que na teoria Neoclássica, os agentes são movidos pelo autointeresse. O oportunismo é definido por Williamson (1985, p. 47) como a busca do interesse próprio com malícia, sendo decorrente da existência de assimetrias de informação. A emergência potencial de oportunismo ex ante e ex post, reside na manipulação de intenções e/ou informações, de modo a auferir lucros que alterem a configuração inicial do contrato. Surgindo, assim, conflitos no âmbito das relações contratuais que regem as relações entre os agentes.

Portanto, dada a incompletude dos contratos a partir destes pressupostos, salvaguardas são essenciais para a redução de ações não desejadas. Para que isso seja possível, devem ser identificadas as dimensões que cada transação apresenta.

Em primeiro lugar, a frequência, que focaliza se ela ocorre repetidamente ou apenas uma vez. A importância dessa dimensão está ligada ao surgimento da reputação das partes envolvidas, sendo um dos mecanismos de controle do oportunismo.

A dimensão que ganha maior presença nos estudos sobre as organizações baseados na ECT é a especificidade dos ativos. O grau de especificidade é medido pela perda potencial de valor dos ativos no caso da transação não se concretizar, como num rompimento contratual, por exemplo. Alta especificidade de ativos significa que uma ou ambas as partes envolvidas na transação perderão, caso esta não se concretize, por não encontrarem uso alternativo que mantenha o valor do ativo desenvolvido para determinada transação. 
Assim, quanto maior é a especificidade, maior a perda de valor em caso de ruptura contratual e daí a necessidade de salvaguardas para evitar a potencial captura de valor pela outra parte. O gráfico, a seguir, resume a escolha da forma de governança de acordo com o grau de especificidade do ativo:

\section{Gráfico 3 - Formas de Governança e especificidade de ativos}

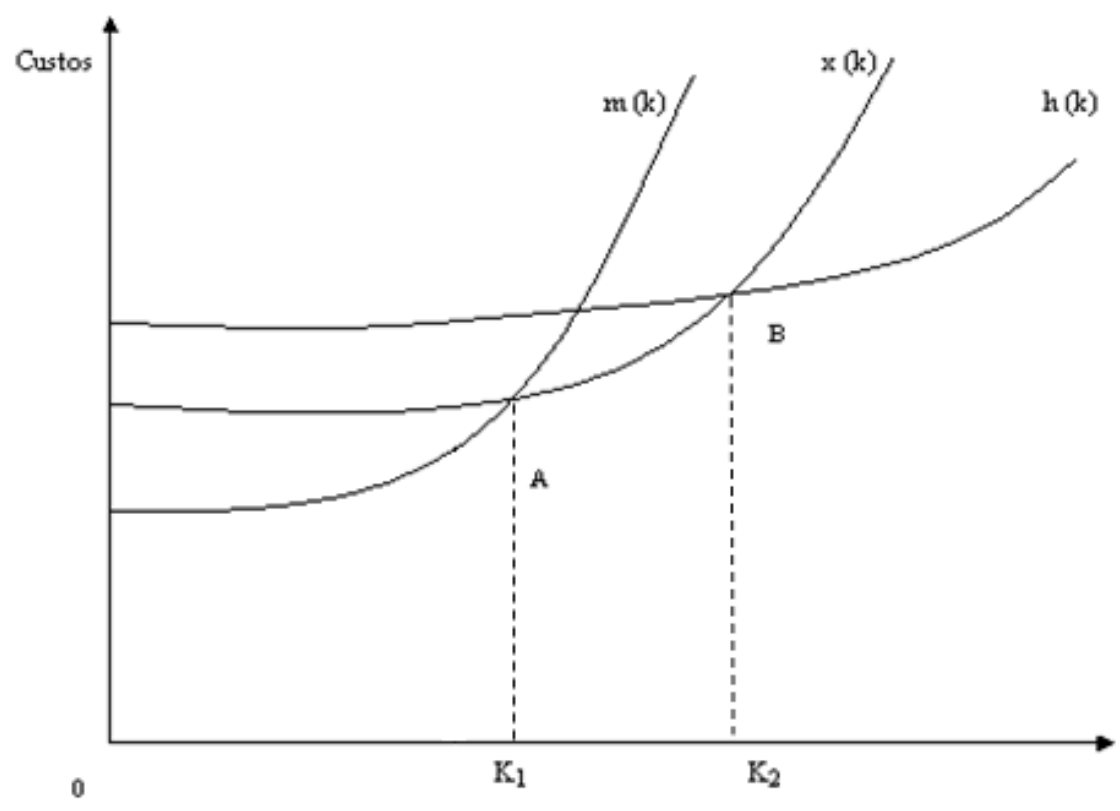

Fonte: Williamson, 1996.

Quando o ativo detém um grau baixo de especificidade $\left(\mathrm{k}<\mathrm{K}_{1}\right)$, o mercado (curva $m(k))$ é a forma de coordenação mais adequada, dados menores custos associados. Entre os pontos A e B $\left(\mathrm{K}_{1}<\mathrm{k}<\mathrm{K}_{2}\right)$ o referido grau aumenta, de forma que a escolha por contratos minimiza os custos. Finalmente, quando os ativos são muito específicos, $\mathrm{k}<$ $\mathrm{K}_{2}$, a alternativa que minimiza os custos é a integração vertical (curva $h(x)$ ).

A terceira dimensão mencionada por Williamson ganha destaque no presente trabalho. A incerteza agrupa forças não previsíveis e seus efeitos sobre os resultados finais de uma atividade econômica. O grau de incerteza deriva do pressuposto da racionalidade limitada dos agentes e conclui-se, assim, que os contratos serão inevitavelmente incompletos. Mesmo assim, Masten (1998) aponta três motivos principais para a 
existência das relações contratuais: a transferências de risco, o incentivo ao alinhamento e a economia dos custos de transação.

O esquema abaixo resume a escolha das formas de governança proposto por Williamson (1985), considerando a possibilidade da existência de ativos específicos. Na ausência de tais ativos, o mecanismo de preços é suficiente (p1 no diagrama). A parte que realiza investimentos em ativos dessa natureza deve adotar mecanismos que reduzam os riscos associados à possibilidade da perda de valor. O nó B representa uma situação de instabilidade, dado que salvaguardas contratuais não são adotadas ( $\mathrm{S}$ igual a zero). $\mathrm{O}$ nó C será eficiente em comparação ao B, pois introduz elementos capazes de evitar a situação de hold-up.

\section{Figura 2 - Esquema contratual simplificado}

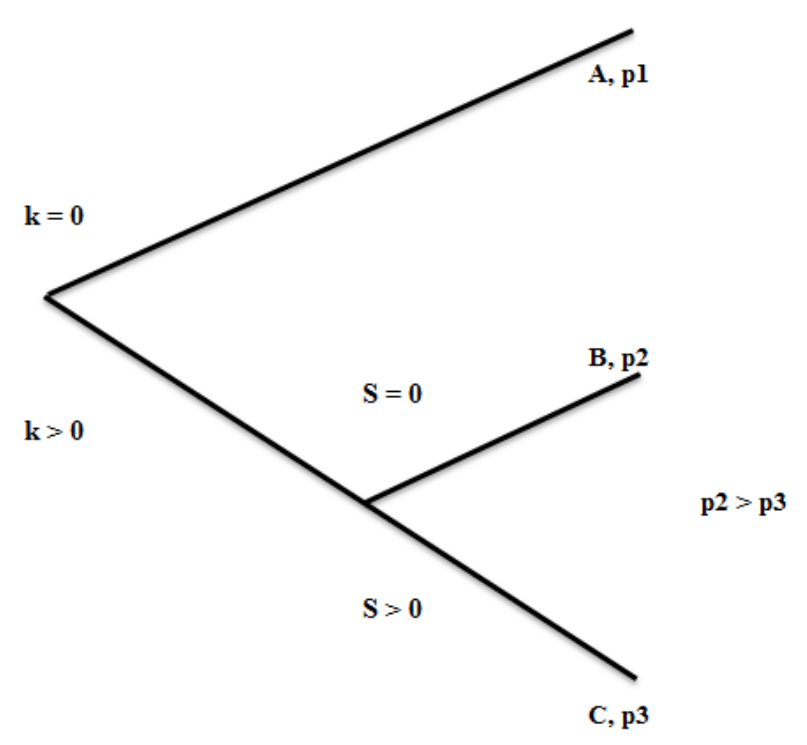

Fonte: Williamson (1996)

A implicação da incompletude dos contratos resulta na definição de como são alocados os direitos de propriedade quando os agentes se encontram em situações não previstas ex ante na sua elaboração. Há dois tipos de direito que deverão ser alocados: direitos específicos, explícitos em contrato, e os residuais, que emergem de circunstâncias não previstas. Este e outros fatores influenciam no desenho e na escolha das relações contratuais. 


\subsection{Escolha Contratual}

Que elementos influenciam a elaboração dos contratos? Conforme Masten (1998), a essência de uma relação contratual está no compromisso e a reputação entre as partes é essencial para que o cumprimento das obrigações seja crível. Quando a reputação não for suficiente para conter o oportunismo, a elaboração de um contrato com possíveis sanções legais torna-se necessária. A natureza incompleta dos contratos e a limitação cognitiva dos agentes em prever e identificar respostas ótimas para os acontecimentos futuros implica que seu desempenho depende do nível de informação que os agentes detêm.

O fato de existirem possibilidades de ganhos de valor não abordadas por um contrato incompleto abre duas modalidades de relações. Primeiramente, aqueles sem a possibilidade de renegociação, os chamados contratos com restrições lineares. Conforme será visto em seguida, tais modelos configuram relações entre uma agente e um principal. Na segunda modalidade, estão os contratos nos quais existe a possibilidade de revisão dos termos inicialmente acordados. A obtenção de ganhos adicionais derivados dessa característica relaciona-se com a aversão ao risco e a realização de investimentos específicos. $\mathrm{Na}$ esfera dessa modalidade, os efeitos observados ex post às renegociações influenciam na reputação dos agentes. Nesse cenário, se faz necessária presença de terceiros, como os juízes, que avaliam as quebras contratuais entre os envolvidos na relação (MASTEN, 1998).

Para Stiglitz (1987), sempre que numa transação uma parte possui alguma informação relevante que a outra desconhece, é possível tirar proveito da relação. Entretanto, a parte que desejar tais informações acabará arcando com custos por buscá-las, que podem ocasionar conforme Akerlof (1970) o problema de seleção adversa. No aspecto contratual, Furubotn e Richter (2000, p.181) compreendem que a seleção adversa lida com o oportunismo ex ante. Em linha com Klein (1999) que o justifica que o comportamento oportunista se deve à ao risco moral observado em contratos anteriores.

Quanto a uma possível solução compensatória ante o risco moral, a teoria institucionalista advoga o estabelecimento de três mecanismos: o monitoramento das condições de execução das cláusulas contratuais; os mecanismos contratuais que 
buscam incentivar ações positivas, ou seja, visa o alinhamento de incentivos; ou, a integração entre as partes, o mecanismo join-ventures (WILLIAMSON, 1985).

Barzel (1997) reflete que, uma vez definidos e formalizados os direitos de propriedade, caberia ao Estado garantir que isso prevaleça. Ocorre que os direitos de propriedade não são bem definidos, ou o Estado falha na alocação e garantia dos direitos.

Williamson (1991) esclarece que a operacionalização de uma análise de escolha contratual e dos custos de transação passa por três estágios. O primeiro agrupa uma análise comparativa mediante: i) a definição da transação como a unidade básica de análise; ii) identificação dos pressupostos comportamentais para a elaboração do contrato e iii) estabelecimento das dimensões críticas da transação. O segundo estágio procura comparar a eficiência das diferentes formas transacionais (mercado, hierarquia), respondendo acerca: i) de quais são os custos associados e ii) como cada forma é implementada. O terceiro estágio implica na observação intertemporal das escolhas do contrato.

Ronald Coase, ao ser laureado com o Nobel (1991), chama a atenção em seu discurso para o estudo das diferentes relações contratuais e formas de governança existentes nas organizações. Os custos associados às transações presentes nas firmas explicam a escolha por relações via mercado ou via contratos. Portanto, as formas de governança alinham-se com a existência dos custos para elaborar, modificar e estabelecer compromissos entre as partes. Mas como tudo isto funciona para as relações contratuais na agricultura? 


\subsubsection{Contratos na Agricultura}

Como são feitas as escolhas entre alugar a terra para terceiros ou produzir para si mesmo? Por que os padrões de propriedade (alugar ou comprar) podem ser distintos para os elementos de produção, como equipamentos? Allen e Lueck (2002) trabalham modelos empíricos com o objetivo de responder questões recorrentes aos contratos agrícolas. Esses autores demonstram a necessidade de abordar os custos de transação para entender as diferentes formas organizacionais nas atividades ligadas à terra.

Cheung (1969) propôs um racional de compartilhamento de risco, para o modelo principal-agente utilizado no estudo das formas organizacionais da agricultura. Existe um trade-off entre os incentivos do agricultor e sua aversão ao risco, dessa forma, os contratos que fornecem os melhores incentivos também implicam maior risco.

Segundo Coase (1937), na ausência dos custos de transação, a alocação dos recursos independe da distribuição dos direitos de propriedade. Sendo assim, um contrato de de parceria entre produtor e o dono de terra (cropshare) poderia alcançar o mesmo resultado em termos de produção do que um contrato de aluguel da terra (Cheung, 1969). Entretanto, para se entender as formas de organizações do mundo real é necessário considerá-los.

Portanto, os direitos de propriedade devem ser definidos via contratos privados ou por meio de terceiros. Assim, são desenvolvidos modelos dependentes da habilidade de policiamento entre as partes, pois surgem problemas de enforcement devido à incerteza da natureza e a complexidade dos recursos envolvidos.

Trata-se de um problema de agência e embora esse não seja o foco do presente trabalho, ele apresenta importantes ideias que definem o arcabouço teórico. Entre eles:

i) As partes envolvidas escolhem contratos e formas organizacionais porque elas maximizam o valor esperado de suas relações.

ii) Os recursos são complexos, pois apresentam muitos atributos.

iii) Ainda que a natureza tenha um componente aleatório derivado da incerteza, existe um componente sistêmico, a sazonalidade. 
iv) Suspensão do pressuposto de aversão ao risco, ou seja, as partes são neutras ao risco.

Sua forma funcional do modelo com base na função de produção neoclássica é dada pela seguinte equação:

$Q=f($ fatores $)+\Theta$

Dado que:

$Q \quad=\quad$ Quantidade produzida.

$\Theta=$ Componente aleatório.

O produto $Q$ é resultado do esforço humano (a função $f$ ) e do componente aleatório $\Theta$ (Teta). Os efeitos dos fatores de produção não são perfeitamente observáveis ou mensuráveis, pois se torna difícil distinguir sua influencia daquela derivada do componente aleatório. Assim, elementos como esforço humano e condições climáticas podem ser indissociáveis analiticamente. Por exemplo, baixos níveis de produção resultantes de baixo esforço humano podem ter seus efeitos ampliados ou reduzidos por más condições climáticas.

Sobre a função $f$, assume-se que apresenta produtividade marginal positiva, porém decrescente. Outro pressuposto reside na independência entre os insumos, dado que simplifica o modelo e torna maior a possibilidade de testar suas implicações. Os preços são considerados como dados: o custo de oportunidade para o produtor é um salário de mercado, w; e de forma análoga, o custo de oportunidade do uso da terra é igual a um aluguel, r. Dada essa estrutura, são incorporadas outras variáveis.

Allen e Lueck (2002) utilizam o modelo acima para analisar as formas organizacionais. O resultado dessa estimação é utilizado como referência para os contratos factualmente observados nas organizações. Embora ele esteja centrado na questão do acesso ao fator de produção terra, é possível encontrar outros elementos importantes pertinentes a discussão deste trabalho. Dois deles são essenciais na condução da abordagem dos custos de transação: 
i) Risco

Sob a ótica tradicional, existe o compartilhamento do risco, sendo este dividido entre diferentes produtores de forma a diluí-lo e transferi-lo ao dono da terra. Autores como Stiglitz (1987), Sappington (1991) e Hayami (1992) apresentam um consenso: contratos de arrendamento da terra mostram um exemplo clássico da relação principal-agente e são basicamente estabelecidos por causa da aversão ao risco. No modelo tradicional, é postulado um dono da terra neutro ao risco e um agricultor avesso ao risco. Se um contrato de arrendamento é estabelecido, ao dividir o uso da terra com o agente, o principal pode sofrer com o risco moral. Dessa forma, surge um trade-off entre aversão ao risco e incentivos imperfeitos. Se o principal aluga a terra para um agente, não existem problemas de incentivo, dado que ele carrega todo o risco associado à produção.

Existem poucos testes empíricos para tais constatações. Na verdade, existem evidências contrárias às suas predições: plantações com maior volatilidade de retorno (portanto maior risco) apresentam maior incidência de arrendamento. Para os autores, é assumido que os participantes são neutros ao risco.

ii) Desenho dos contratos

Quais elementos podem ser citados, de forma a corroborar a percepção da complexidade desses contratos? É necessário atentar para os seguintes aspectos:

\section{ii.1) Risco Moral}

Segundo Nahas (2001), os contratos agrários que focalizam o acesso à terra são basicamente os de parceria e de arrendamento. Esses contratos propiciam esteio para formar propriedades agropecuárias de caráter temporário e rudimentar (IBGE, 1998). Os parceiros e os arrendatários são trabalhadores assalariados "disfarçados". Assim, a forma como se comportam pode influenciar o resultado futuro da produção, ainda mais considerando que o dono da terra pode apresentar baixo interesse na produção. Dessa forma, existe um problema de risco moral para os dois lados do contrato. A lógica é a de que os agricultores podem não ser tão cuidadosos ou esforçados quanto se possuíssem de fato a terra e aquilo que é dela extraído. Existe a necessidade de se assegurarem as estipulações contratuais (enforcement), o que reforça a importância das instituições. 


\section{ii.2) Complexidade}

É necessário considerar a complexidade dos acordos. Se os contratos especificam detalhes técnicos (como níveis dos insumos) contratos mais longos se tornam necessários, com determinações adicionais para lidar com os fatores que variam ao longo do tempo. Para os contratos agrícolas existem três determinantes para que eles sejam considerados simples: i) a presença de especificidade de ativos; ii) a viabilidade do enforcement dos contratos; iii) as leis que viabilizam o cumprimento dos contrato. É válido mencionar que existe o enforcement de mercado, ou seja, as ações derivadas do efeito reputacional. $\mathrm{O}$ aparato institucional, com leis bem definidas, pode contribuir para diminuir a necessidade de contratos complexos.

\section{ii.3) Especificidade de ativos}

Klein, Crawford e Alchian (1978) e Williansom (1979) apontam que, na existência de ativos específicos, os agentes se encontram potencialmente numa situação de exposição ao oportunismo na forma de captura de valor - hold-up - diante de uma renegociação de um contrato de curto prazo. Isto ocorre, pois cada parte poderia tentar extrair a quase-renda da outra, haja vista que os investimentos em ativos específicos já teriam sido realizados. Dentro dos contratos agrícolas, isto pouco ocorre devido à baixa especificidade dos ativos. Num caso extremo, o problema do hold-up poderia acontecer se o contrato de aluguel de terra fosse menor que a duração do ciclo da colheita, sendo necessária uma renegociação durante o processo produtivo. Entretanto sabe-se que os contatos sempre cobrem o ciclo de produção.

\subsubsection{Outros modelos de desenho contratual}

É possível encontrar outras abordagens sobre escolhas contratuais na agricultura. Uma delas explora o efeito catraca (ratchet effect), ou seja, o efeito reputacional a partir do comportamento daqueles que alugam a terra de terceiros, dado que é possível detectar comportamento oportunista de sua parte.

Outra delas contempla um modelo com o trade-off entre adquirir e alugar os insumos, como equipamentos. Mediante testes empíricos, pôde-se encontrar que: i) os riscos 
morais aumentam a probabilidade de aquisição dos insumos; ii) maior especialização reforça a escolha por contratos; iii) a presença de ativos específicos influencia a aquisição dos fatores de produção.

Mondelli (2007) identificou os determinantes da escolha dos arranjos contratuais na transação produtor-processador de carne bovina no Uruguai. De modo particular, analisaram-se as dimensões da transação: especificidade dos ativos envolvidos, frequência e incerteza. Identificaram-se os determinantes da escolha dos arranjos contratuais dominantes (direto e via intermediário). Uma transação tem maior probabilidade de se alinhar com o arranjo contratual direto (mais coordenado): i) quanto maior for o grau de especificidade dos ativos; ii) quanto menor a distância entre o produtor e o processador (maior especificidade locacional) e iii) quanto maior a frequência das transações entre as partes envolvidas.

Rezende (2008) analisou as quebras contratuais por parte dos produtores de soja em um momento de expressiva alta do preço e suas consequentes disputas judiciais. O contrato de compra e venda antecipada de soja mostrou-se incapaz de atuar como mecanismo eficiente para enfrentar grandes oscilações de preço. Alguns produtores preferiram os ganhos de curto prazo em detrimento de ganhos de longo prazo que seriam resultantes da manutenção da relação com a indústria/trading. Mais relevante que o número de contratos quebrados foi a repercussão do fato. As consequências mais citadas foram: maior exigência de garantias para crédito e custeio, maior dificuldade para negociar com a empresa e a redução do volume de contratos de venda antecipada efetuados. O contrato existe para reduzir o risco, logo, o instrumento contratual, na forma como foi praticado, mostrou-se frágil, devido à instabilidade do ambiente institucional.

\subsection{Alocação do Risco}

Furquim (1996) observa três definições para o risco. A primeira consiste na visão neoclássica, sob a qual há de se considerar a variância de uma distribuição de probabilidades, à qual se associa o grau de aversão ao risco dos agentes. O risco neoclássico associa-se à teoria do consumidor. Conforme Varian (2003), eventos aleatórios influenciam a escolha da cesta de consumo ou a escolha de um mix de produtos de um indivíduo. Nessa discussão, é preciso introduzir o conceito de aversão 
ao risco que, intuitivamente, implica que, ao enfrentar escolhas com retornos comparáveis, os agentes tendem a escolhera a alternativa menos arriscada. Essa construção se deve em grande parte ao trabalho de Friedman e Savage (1948). O gráfico a seguir mostra a relação entre o nível de utilidade (eixo Y) conferido a cada unidade de consumo (eixo X).

Gráfico 4 - Propensão ao Risco: Visão Neoclássica

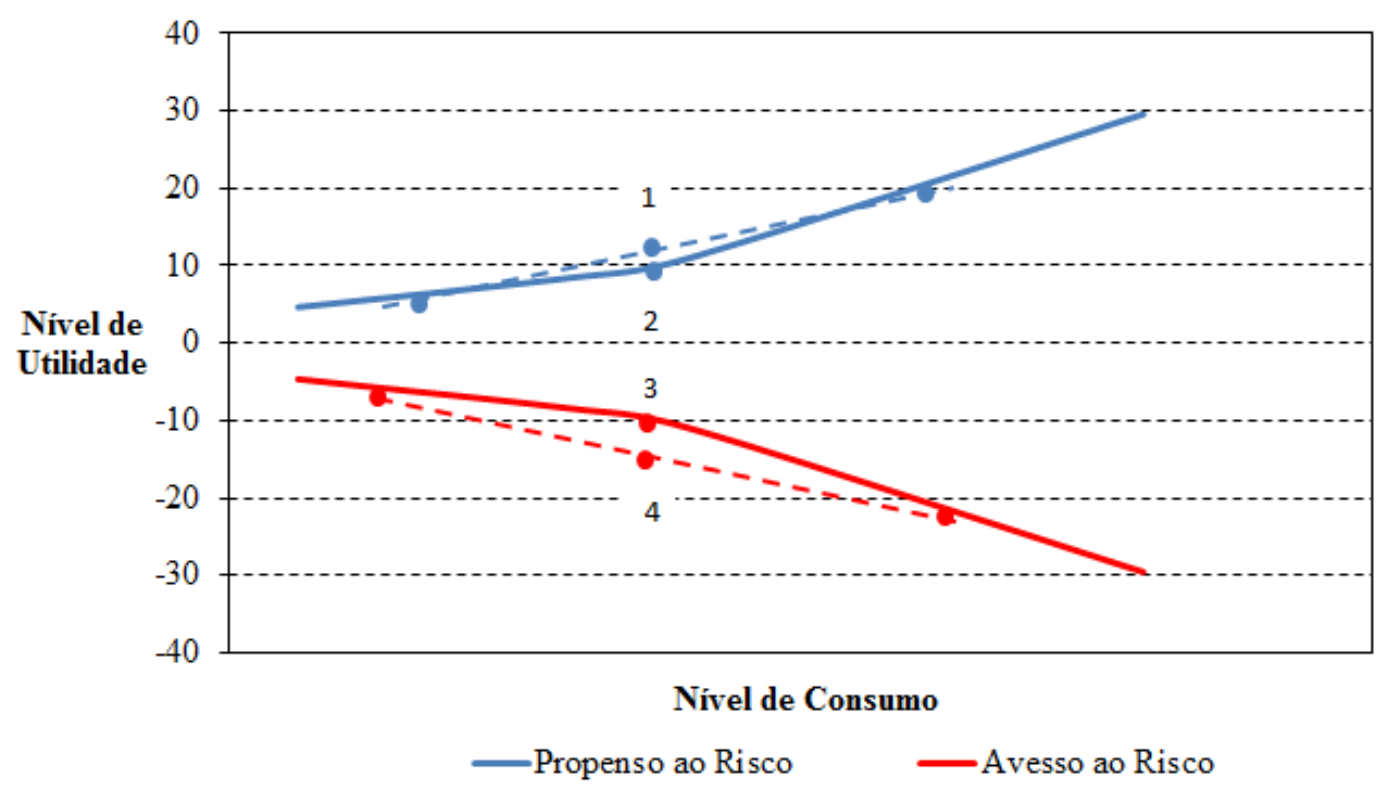

Fonte: Varian (2003)

Cada nível de utilidade se associa a uma probabilidade de ocorrência, de forma que o indivíduo propenso ao risco (linha azul) prefere a utilidade esperada do consumo ponto 1 no gráfico - à utilidade do consumo esperado - ponto 2. A utilidade esperada é dada pela utilidade de dois pontos quaisquer da curva azul ponderada pela sua respectiva probabilidade. A utilidade do consumo esperado é a utilidade da média de dois pontos quaisquer na curva. O indivíduo avesso ao risco (linha vermelha) prefere a utilidade do consumo esperado - ponto 3 no gráfico - à utilidade esperada do consumo - ponto 4 .

A construção dessas curvas ajuda também a observar o prêmio de risco de risco dos agentes, representado no gráfico pelas distâncias verticais entres os pontos 1 e 2 (indivíduo propenso ao risco) e 3 e 4 (avesso ao risco). Ele é definido como a quantia 
máxima que os agentes estão dispostos a pagar para evitar determinado risco de forma que se tornem indiferentes entre recebê-lo e receber uma quantia certa.

Tal risco é derivado dos chamados estados da natureza aos quais se associam probabilidades estimadas, que ajudarão a explicar como os agentes alocam suas preferências. A partir dessa abordagem, Williamson (1991) argumenta que o risco pode crescer: i) "se a distribuição de probabilidades dos distúrbios permanece inalterada, mas um número maior de distúrbios ocorre ou ii) se os distúrbios se tornam intrinsecamente mais importantes, dado o aumento da variância.

Knight (1921) faz a distinção entre os significados de risco e incerteza. Sua ideia básica está na separação entre esses elementos: os riscos associam-se a impactos que geram variabilidade, cuja função de probabilidade é conhecida. Já a incerteza, em seu estado puro, não permitirá tal mensuração.

Uma segunda abordagem, em linha com North (1990), versa que a incerteza advém da impossibilidade de conhecimento pleno dos acontecimentos futuros. Nesse sentido, ela inviabiliza a estimação e a definição de uma distribuição de probabilidades. Tal tratamento se distancia daquele empregado na teoria da escolha neoclássica: os mecanismos de governança devem se adequar ao objetivo de mitigar a incerteza.

Existe ainda um terceiro ponto, no qual Milgrom \& Roberts (1992) enfatizam o aspecto informacional da incerteza. Há incerteza quanto ao reconhecimento das informações relevantes ao contrato, ou, mais precisamente, quando a informação é incompleta e assimétrica.

O reconhecimento da 'incerteza' permite estabelecer os limites da racionalidade e, portanto, evidenciar a incompletude dos contratos, relação já tratada por Arrow (1963), ao reconhecer "que o esquema de contratos contingentes era tão complexo que poderia se tornar incompreensível ou excessivamente caro".

Conforme Zylbersztajn (2005), ao analisar o mapa cognitivo das transações de Williansom (1985): "os contratos surgem como estruturas de amparo às transações que visam controlar a variabilidade e mitigar riscos, aumentando o valor da transação ou de um conjunto complexo de transações". Dessa forma, os fatores que influenciam os resultados futuros podem ser mapeados e até determinado grau, contidos. Neste trabalho 
o uso do termo fator de risco aponta para as variáveis de diferentes naturezas que geram incerteza para os cafeicultores.

Traçando um paralelo com as teorias de finanças, a questão da gestão dos fatores de riscos vem ganhando relevância dentro do contexto das organizações. Dada a interdependência dos mercados, as empresas tornam-se mais vulneráveis a tais fatores.

Aspectos econômicos e competitivos afetam os resultados das empresas. Conflitos de agência, por exemplo, são decorrentes de problemas de assimetria de informação e constituem imperfeições de mercado que apontam para o uso de mecanismos de gestão de riscos. Sabendo-se que o acesso à informação não é uniforme e supondo-se que os agentes têm disposição a maximizar a própria utilidade em detrimento dos objetivos dos principais, a gestão de risco torna-se relevante por sinalizar ao mercado as possibilidades da ocorrência de problemas de agência.

A teoria sobre gestão de riscos fundamenta-se em, praticamente, duas abordagens. A abordagem tradicional para o hedge em corporações não financeiras tem como origem o trabalho de Stein (1961) que analisa o uso de contratos futuros para a proteção de exposições financeiras. Posteriormente, Ederington (1979) popularizou a abordagem investigando os investimentos em contratos futuros como uma maneira de contrabalancear o risco. A abordagem tradicional supõe que a empresa, por se comportar como um investidor avesso a risco, busca sua minimização.

A abordagem mais moderna de gestão de riscos leva em consideração os estudos de Jensen e Meckling (1976) sobre as relações contratuais existentes dentro de uma empresa. Devido aos possíveis conflitos de interesse entre administradores, acionistas, credores e demais personagens associados à empresa, a necessidade da gestão de riscos pode depender das relações entre os stakeholders, decorrentes da forma de remuneração, da assimetria de informação e do perfil de risco. Os modelos modernos de otimização da função de gestão de riscos envolvem a identificação de premissas que regulam as relações de agência ou os conflitos de interesse existentes na empresa.

Heaney e Poitras (1991) obtêm índices ótimos de hedge a partir de dois conjuntos de premissas diferentes. Supondo que os retornos dos preços à vista e dos preços futuros têm distribuição conjunta normal bivariada, os autores derivam os índices de hedge a partir de regressão de mínimos quadrados e de funções de utilidade predeterminadas. 
Myers (2000) compara duas abordagens para a estimação de índices ótimos de hedge que variam com o tempo. Por meio do estudo de variâncias e covariâncias de commodities agrícolas, o autor estabelece o condicionamento de informação com graus diferentes de sofisticação. Assim, na primeira abordagem, são calculadas variâncias e covariâncias amostrais móveis dos erros de predição de preços à vista e preços futuros. $\mathrm{Na}$ segunda abordagem, são obtidas estimativas de variâncias e covariâncias mediante modelos autoregressivos generalizados de heteroscedasticidade condicional.

Ross (1996) identifica uma carteira de hedge ótima que possibilita a maximização do valor da empresa, na qual a gestão de riscos possibilita um aumento do índice ótimo de endividamento, fazendo com que a empresa obtenha maiores benefícios fiscais. Nesse caso, a gestão de riscos tem um papel indireto ou secundário, uma vez que o hedge traz incrementos de segunda ordem na riqueza do acionista.

Existem muitas tipologias para risco que atendem a distintos propósitos. Conforme a classificação do Comitê da Basiléia de 1997, em seu documento Core Principles for Effective Banking Supervision (Basel Core Principles), estão sugeridos os seguintes tipos de riscos: risco de crédito, risco país e de transferência, risco de mercado, risco de taxa de juros, risco de liquidez, risco legal, risco reputacional e risco operacional. 


\subsection{O Sistema Agroindustrial do Café}

O sistema agroindustrial do café compreende diversos agentes, entre eles: vendedores de insumos, produtores agrícolas, diferentes atacadistas especializados, traders, cooperativas, indústrias de torrefação e solúvel e varejistas. O presente trabalho se dedicará a verificar as relações contratuais ocorridas a partir da produção do café. Baseados na figura a seguir, o SAG do café pode ser estudado de acordo com as características das transações que ocorrem ao longo do sistema.

\section{Figura 3 - O Sistema Agroindustrial do Café}

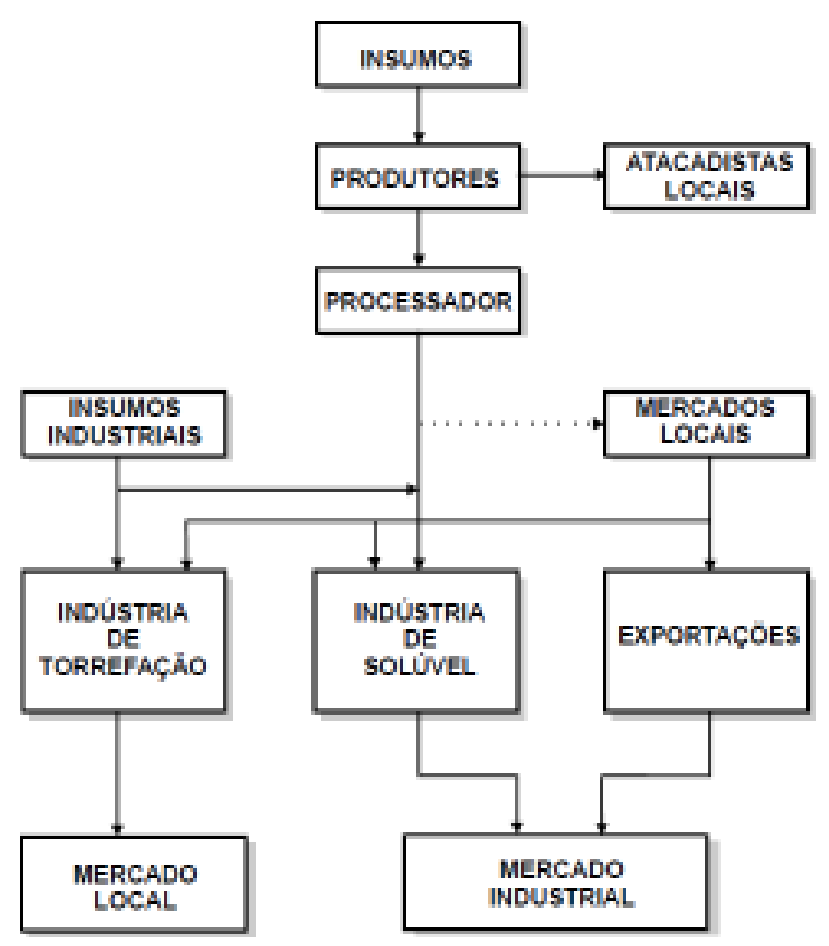

Fonte: Zylbersztajn (1995)

A destinação do produto é tanto para o mercado doméstico como internacional. A exportação mundial no ano cafeeiro 2010/2011, que corresponde ao período de outubro de 2010 a setembro de 2011, apresentou elevação de 9,4\%, atingindo 103,1 milhões de sacas de 60 quilos, contra os 94,3 milhões de sacas do período anterior. Conforme a Organização Internacional do Café (OIC), o resultado corresponde a um volume histórico recorde. 
A receita com as exportações de café dos primeiros dez meses de 2011 foi $61 \%$, superior à registrada no período imediatamente anterior e atingiu US\$ 7,01 bilhões, com o embarque de 27.357.020 sacas. Os dados são do Balanço das Exportações divulgado hoje pelo CeCafé (Conselho dos Exportadores de Café do Brasil). As exportações de café apresentaram, em outubro de 2011, uma das maiores receitas já registradas para o mês, chegando a US\$ 870,988 milhões. O crescimento foi de $32,8 \%$ em relação ao mesmo período de 2010, quando o resultado registrado atingiu US\$ 655,678 milhões.

O esquema inicialmente proposto para o SAG do café pode ser montado também com a inclusão de Subsistemas Estritamente Coordenados. É possível, desta forma, reduzir o nível de agregação das transações do $\mathrm{SAG}$, reconhecendo que os contratos travados entre os agentes são feitos de forma estratégica. Esse conceito permite o estudo de estratégias de cooperação entre as firmas e suas transações, sendo possível explorar toda a complexidade dos sistemas.

Figura 4 - Subsistemas Estritamente Coordenados

Ambiente Institucional

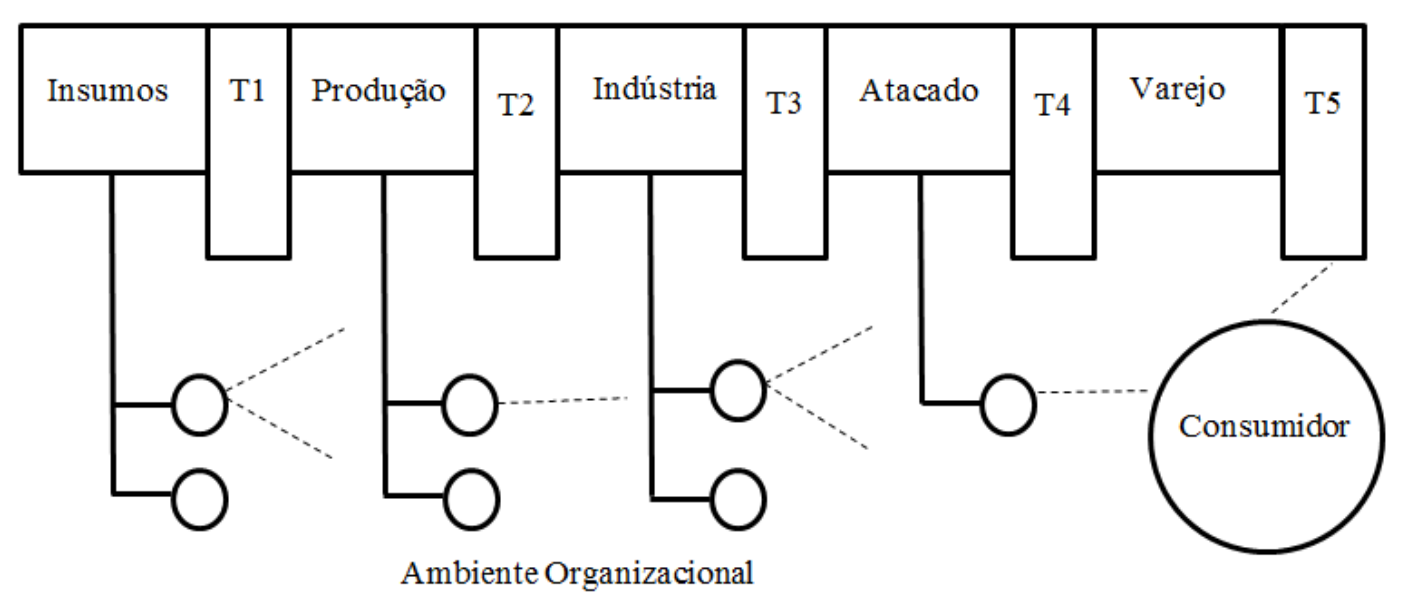

Fonte: Zylbersztajn (2005)

De acordo com o CeCafé, o volume exportado (3.088.737 sacas entre verde, torrado \& moído e solúvel) apresentou uma queda de $11 \%$ em outubro deste ano quando comparado ao mesmo mês de 2010, quando foram exportadas 3.490 .548 sacas. Apesar da queda do volume total exportado, impulsionada pela redução nos embarques de café 
solúvel e arábica, as exportações de robusta/conillon tiveram alta de 102\% quando comparamos esse mesmo período, 232.572 sacas exportadas em outubro de 2011 versus 114.957 sacas exportadas em outubro de 2010.

O SAG do café no Brasil é influenciado por diferentes fatores, que neste trabalho são mencionados como fatores de risco. O aspecto climático (como geadas nas áreas de produção como as ocorridas em 1975 e 1994) e o aspecto institucional são exemplos importantes. Nesse sentido, dois exemplos citados por Zylbersztajn (1995). Em primeiro lugar, as intervenções governamentais nos mercados que impediram que incentivos para melhoria da qualidade chegassem aos produtores, resultando em um produto final bastante homogêneo e em geral de baixa qualidade. Em segundo, as medidas de desregulamentação implementadas após 1990 resultaram em alterações nas condições de competição existentes. Após a desregulamentação dos preços os fortes sinais providos pelo mercado passaram a motivar os produtores a melhorar a qualidade do produto final. Dessa forma, a tendência observada tem sido de uma indústria crescentemente diversificada.

No Brasil, o plantio do café teve início no estado do Pará, em 1727, trazido pelo militar Francisco de Melo Palheta. Expandiram-se pela região Nordeste, atingindo, em 1825, o Vale do Paraíba Em função do clima e da fertilidade das terras, concentrou-se nos estados de Minas Gerais e São Paulo. Foi no começo do século XX, de fato, que a commodity, devido às exportações, levou o nome do País aos vários pontos do mundo.

Como a comercialização do produto entre os agentes econômicos gerava muito risco de preço, era necessário criar um mecanismo de proteção contra os diversos fatores que influenciavam a formação desse preço. O primeiro contrato futuro de café do mundo foi lançado pela Bolsa de Café da Cidade de Nova Iorque em 1882, ano em que foi fundada.

Em 1986, a CSCE introduziu o mercado de opções sobre futuro de café. Em 2004, a CSCE e a New York Cotton Exchange (NYCE), esta fundada em 1870, transformaramse na New York Board of Trade (NYBOT). A produção brasileira de café (arábica e robusta) alterna períodos de grande atividade com outros de retração, em parte devido ao ciclo bianual da cultura. Apesar da característica relativamente cíclica da produção, a tendência de longo prazo evidencia a ocorrência de apreciáveis ganhos de produtividade 
e a manutenção do Brasil como o maior produtor mundial de café. Da produção brasileira, $75 \%$ correspondem à variedade arábica. Os $25 \%$ restantes são do tipo conillon (robusta). Minas Gerais responde, isoladamente, pela fatia de 50\% da produção total do País. O comportamento dos preços internacionais do café arábica, segundo dados da Organização Internacional do Café (OIC) é ilustrado a seguir:

\section{Gráfico 5 - Indicador Histórico Internacional - Preço Médio Anual}

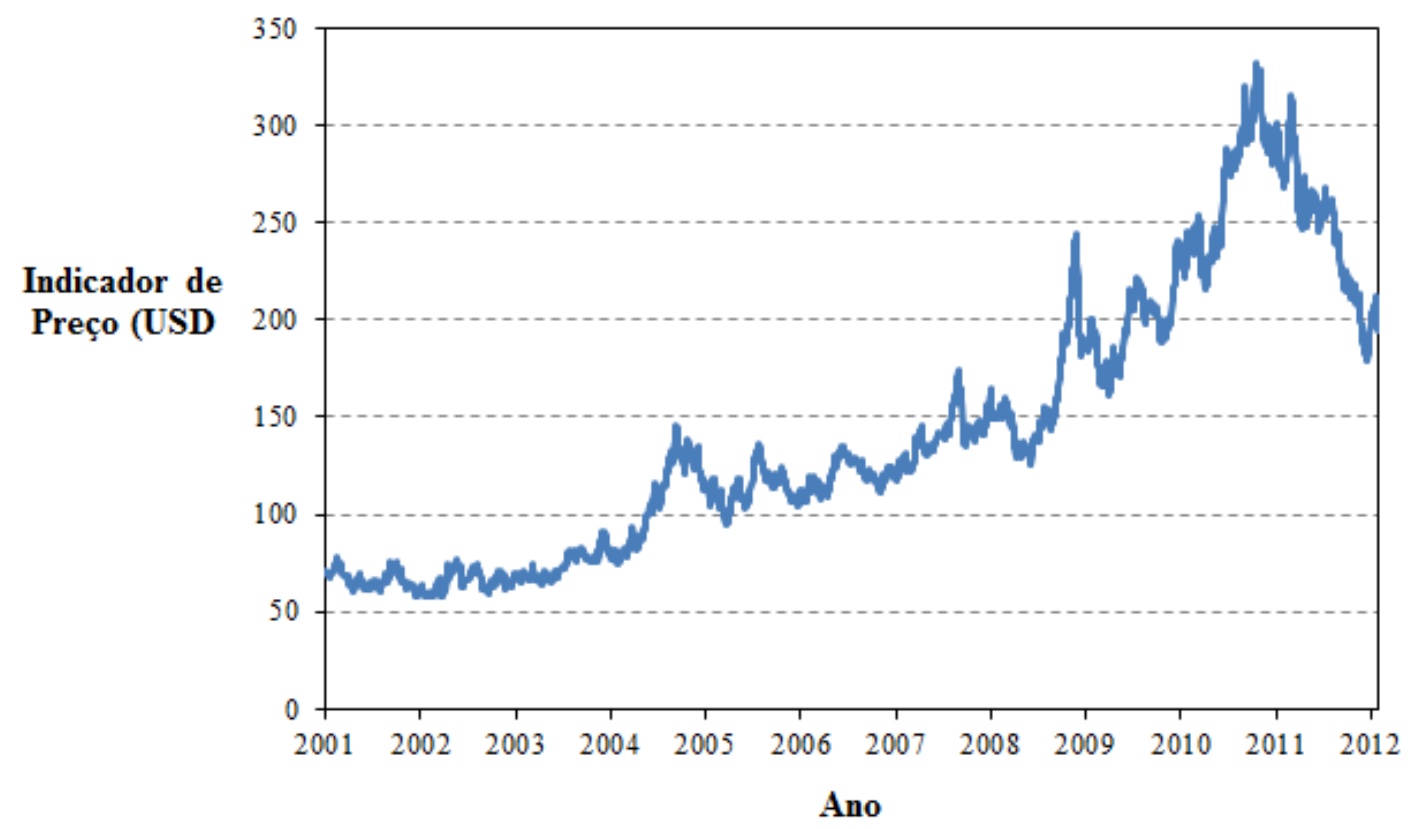

Fonte: Organização Internacional do Café (2011)

A série temporal mostra trajetória declinante desde 1984 - com alguma recuperação em 1995 e 1997. Uma segunda é a variação percentual acumulada (36\% negativos) desde 1984 até 2004, quando se observa um aumento consistente em seu valor. A observação de um ciclo de baixa (entre 1996 e 2001, linha tracejada vermelha) e um de alta (entre 2002 e 2011) será explorada para analisar a decisão do produtor.

O perfil claramente errático do comportamento dos preços do café - e as perdas significativas que tal perfil pode impor aos produtores - revela que a utilização dos mercados futuro e de opções como ferramentas de administração de risco é requisito fundamental para o cafeicultor e também para todos os participantes do mercado cafeeiro que precisam de um horizonte de planejamento e de segurança para a comercialização e o financiamento do produto. 
Conforme Saes e Farina (1999) o SAG do café foi responsável por 5\% do total das receitas de exportações brasileiras, o que significa US\$ 2,6 bilhões de divisas com exportação. Apesar desse resultado favorável, a participação do Brasil no mercado internacional do café tem sido decrescente. Na década de 60 , o Brasil deteve $40 \%$ do total da produção mundial de café, ao passo que nos anos 90 sua participação está ao redor de $20 \%$. Entre as tendências identificadas no segmento consumidor de café, as autoras apontam o crescimento do consumo de tipos especiais tanto no Brasil como no exterior, estagnação do consumo de cafés tradicionais nos países desenvolvidos, aumento da participação de produtos à base de cafés (café gelado em lata, cappuccino, balas de cafés e shake) no total das vendas de café no varejo, aumento da participação dos grandes supermercados na comercialização do café e aumentos das vendas de cafés em lojas especializadas.

Desde meados da década de 1990, a produção mundial de café tem apresentado aumentos significativos não acompanhados pela respectiva elevação do consumo. Houve expressivo crescimento do parque cafeeiro na maioria dos países produtores, com destaque para Vietnã e Brasil. As cotações, por sua vez, iniciaram uma prolongada queda entre 1997 e 2001, apresentando recuperação consistente a partir de 2002, conforme dados da OIC.

Essa recuperação se deu em função de fatores como o crescimento dos volumes de financiamento, a implementação de políticas de incentivo e o fortalecimento das cooperativas agropecuárias. As cooperativas (que podem ser apontadas como uma integração vertical da produção) são caracterizadas como uma empresa em que os membros trabalham conjuntamente, buscando um fim comum. A Internacional Cooperative Alliance (ICA) define o cooperativismo como um modelo socioeconômico fundamentado na reunião de pessoas e não no capital, visando às necessidades do grupo e não do lucro, buscando prosperidade conjunta e não individual.

A geração de renda poderá ser mais elevada para o produtor cooperado, pois é plausível supor que a formação de cooperativas gere vantagens competitivas. 
Zylbersztajn (1995) descreve as transações existentes no SAG do café, de modo que para este trabalho, o interesse principal está sobre as transações de venda entre dealers e cooperativas com a venda de grãos para os exportadores e indústrias de torrefação ${ }^{1}$.

A formação dos preços é fortemente influenciada pelos movimentos dos preços internacionais, ainda condicionado ao tipo de produto cultivado. Vale ressalvar que quando o produto é entregue na cooperativa, ele perde a identificação de procedência, o que sugere a necessidade sobre o monitoramento da qualidade de um produto para outro. Os incentivos são, todavia, providos pelo sistema de preços e não emerge a necessidade de esforços para o desenho de contratos.

O café é colhido uma vez ao ano, sendo estocado e colocado no mercado segundo as necessidades dos cafeicultores. Quais os determinantes da escolha final sobre como negociá-lo? O produtor de menor porte terá necessidades financeiras distintas do grande ou daqueles cooperados. Como essa questão é tangida pela observação dos fatores de risco observados pelos cafeicultores? Esses pontos tangentes ao problema inicial surgem pela observação da transação de interesse que esse SAG contém a de venda do café.

\subsubsection{A transação de venda do café}

A possibilidade de estocagem do café permite ao produtor a atuação em distintas frentes de transação. É possível vendê-lo no mercado à vista, a cooperativas agrícolas, atuar no mercado futuro, elaborar contratos específicos com a indústria ou simplesmente estocálo. As escolhas podem também ser simultâneas.

Apesar da pouca liquidez dos contratos futuros de commodities agropecuárias na BM\&F, o café destaca-se no mercado de futuros do Brasil. Tanto em termos do número de contratos negociados, como em termos de volume financeiro envolvido nessas

1 Certas indústrias mantêm agentes compradores nas regiões produtoras e atuam também como atacadistas revendendo o produto para outras indústrias e para exportadores e para tais casos as cooperativas desempenham importante papel nestas transações. 
transações. Esse fato é reflexo das acentuadas flutuações de preços ao longo do tempo, que caracterizam o mercado spot de café.

Assim sendo, o conhecimento do comportamento dos preços é útil nas tomadas de decisões com relação ao planejamento da produção, à manutenção e formação de estoques, dentre outras, podendo, assim, aproveitar de maneira mais eficiente as fases de baixa e de alta nos preços, para a maximização dos lucros.

A volatilidade reflete a intensidade e frequência das flutuações dos preços, demonstrando a sensibilidade do produto às mudanças de informações nas questões políticas, de mercados e nos indicadores financeiros, nacional e internacional. Essa flutuação pode ser sazonal, com periodicidade anual, que tem como causa principal os efeitos das estações do ano na produção e, em consequência, na oferta e na demanda do produto. Pode ser também cíclica, de longo prazo, se repetindo de forma constante. Ambas são causadas pelas características das respostas da oferta e demanda do produto às variações de preços e suas durações variam de seis a oito anos.

Este trabalho se interessa em contrapor as escolhas entre vender no mercado a vista e fazê-lo via contratos de entrega futura, dentro de um horizonte de tempo que agrupe distintas safras subsequentes. A negociação no mercado spot pode ser atraente no curto prazo se o preço da saca estiver apreciado, sendo, dessa forma, possível auferir ganhos advindos de um ciclo de alta.

Figura 5 - A transação de interesse

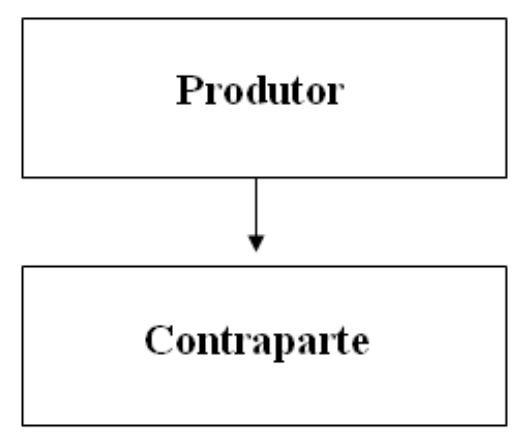

Fonte: $\mathrm{O}$ autor

Contratos de entrega futura de café embora possam garantir ao produtor uma transação capaz de gerar um mercado disposto a receber seu produto, atuam na contramão da 
obtenção dos ganhos de curto prazo. Dentro de um ciclo de alta, eles perdem atratividade, dado que podem não resultar em lucros extraordinários. Para um ciclo de baixa do preço da saca, eles são interessantes.

Dessa forma, as preferências intertemporais dos cafeicultores devem ser observadas: aqueles com uma maior necessidade de recursos financeiros no curto prazo sentirão maior atração pelo mercado. A contrapartida, porém, não necessariamente é verdadeira. Portanto, o questionamento sobre o porquê da escolha transacional do produtor torna-se relevante não apenas por contrapor o pressuposto teórico de mitigação do risco, mas também por fugir a essa lógica. Se o produtor não está num cenário com necessidade de capital de giro, por que mesmo assim não busca relações contratuais de longo prazo? As hipóteses de pesquisa ajudarão a trazer as respostas. 


\section{HIPÓTESES DE PESQUISA}

O produtor depara-se com o trade-off ilustrado a seguir. Ele poderá estocar ou transacionar suas sacas de café. Ao optar pela sua negociação, depara-se com arranjos institucionais, formas de governança para efetuar tais transações de venda.

Figura 6 - Trade-off do cafeicultor

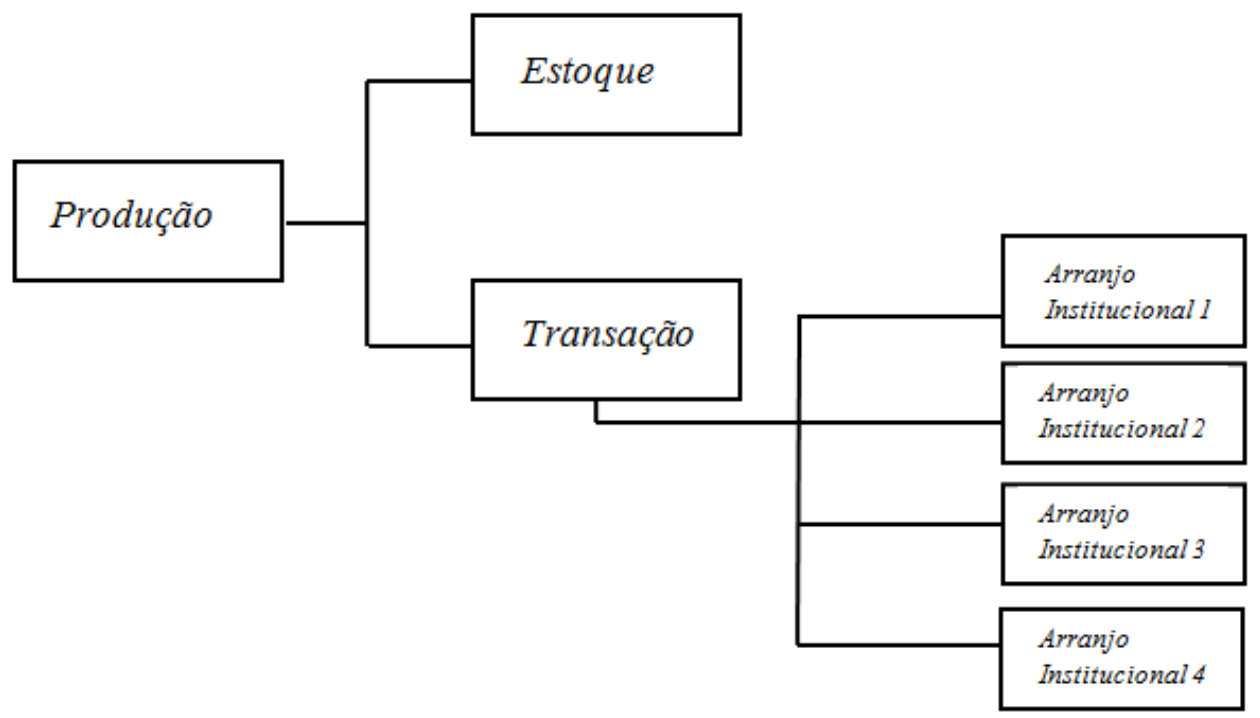

Fonte: O Autor

Com base nas evidências iniciais obtidas com os atores do mercado de café, procura-se entender a atuação preponderante dos cafeicultores no mercado spot. A intenção desta pesquisa é de identificar as razões dessa escolha em detrimento de elaboração de contratos com alocação de risco. Essa escolha pode ser considerada sempre como alternativa superior e eficiente?

A resposta pode ser afirmativa considerando-se uma única transação de venda de café com entrega em determinado instante de tempo. Mas e se forem observados períodos consecutivos? A opção pelo mercado spot deve ser observada em diversos períodos contratuais, no longo prazo. Conforme mencionado anteriormente, cada transação representa uma negociação de entrega de café (mesmo que seja numa data futura), na qual o produtor recebe pelo produto que entrega um preço acordado. 
Ressalve-se que o produtor não é aqui tratado como um agente irracional: sua escolha, embora esteja direcionada para uma transação de curto prazo, não ignora momentos e expectativas a respeito do futuro. O ponto da discussão aqui conduzida (sendo também o elemento analítico) é a transação. Ela, sim, é de curto prazo, com uma entrega subsequente ao momento da safra, ao invés de entregas futuras ao longo de um período mais extenso.

Dessa forma, a hipótese central de pesquisa a ser analisada é a seguinte:

\section{H1. A escolha do produtor por contratos spot é eficiente considerando a geração de renda, aversão ao risco e percepção quanto à segurança institucional.}

Retomando o diagrama mostrado na introdução deste trabalho, essa hipótese equivale à análise do trecho selecionado em vermelho. A decisão sobre como o produtor negocia seu café gera renda de forma eficiente, ou seja, deve ser condicionada à percepção dos fatores de risco.

Figura 7 - A decisão do produtor implica geração de renda

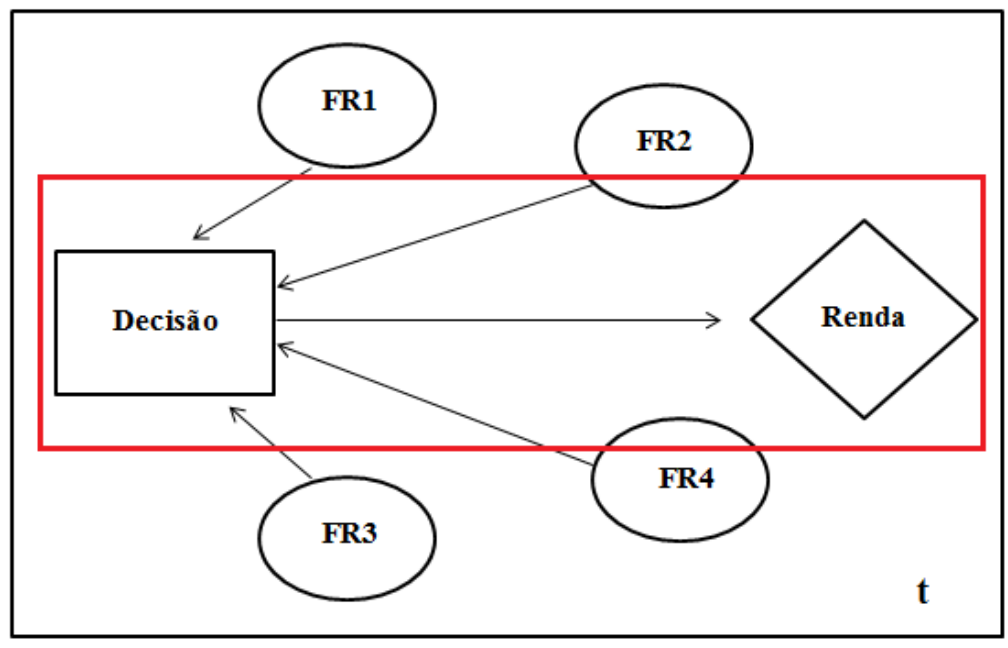

Fonte: $\mathrm{O}$ autor

O diagrama corresponde ao dilema proposto para um compromisso de entrega de café em dado instante de tempo. Com vistas a estudar essa hipótese, os possíveis resultados das decisões serão observados em horizontes maiores, com períodos subsequentes. Será avaliado se a decisão que proporciona o melhor resultado sob a perspectiva da geração 
de renda é a mesma tanto para uma única transação no instante de tempo inicial quanto para diversos e sucessivos períodos.

Partindo para a formalização algébrica, essa hipótese equivale à resolução do seguinte problema. A renda $R_{t}^{j}$ é aquela obtida por determinada forma transacional $\boldsymbol{j}$ num instante de tempo $\boldsymbol{t}$. Existem $\boldsymbol{N}$ instantes de tempo e $\boldsymbol{J}$ formas transacionais:

$\mathrm{Em} \quad t=1$

$\mathrm{R}_{\mathrm{t}=1}^{1}>R_{\mathrm{t}=1}^{\mathrm{j}}$

Neste instante, a renda obtida pela negociação do café por meio da forma transacional 1 (mercado spot) é superior a qualquer outra forma $\boldsymbol{J}-1$ de fazê-lo.

Considerando as formas transacionais ao longo dos $\boldsymbol{N}$ instantes, a relação inicial se mantém? Para verificar essa indagação é necessário obter o valor presente da forma transacional $\boldsymbol{l}$ (mercado spot) ao longo de $\boldsymbol{N}$ instantes e compará-lo com o valor presente das outras $\boldsymbol{J}-\mathbf{1}$ transações.

Para $t=1,2,3, \ldots, n$

$\sum_{t=1}^{n} \frac{R_{t}^{1}}{(1+r+y)^{t}} \geq \leq \sum_{t=1}^{n} \frac{R_{t}^{j}}{(1+r+y)^{t}}$

O desconto intertemporal é feito pela soma da vaiável $r$, a taxa de juros livre de risco, somada com a variável $w$, que representa o prêmio de risco. Esse elemento tem relação direta com a propensão do risco do produtor, Para a análise proposta, o prêmio de risco será:

i) Positivo, caso o produtor seja avesso ao risco.

ii) Negativo, caso o produtor seja propenso ao risco.

iii) Zero, caso o produtor seja neutro ao risco.

Posto isso, a eficiência poderá ser avaliada sob a ótica da geração de renda. Além de entender se a decisão pelo mercado spot é eficiente intertemporalmente sob esse ponto de vista, é instigante identificar qual a influência da percepção do risco na decisão sobre 
a forma de negociar o café. A segunda hipótese de trabalho pode ser ilustrada pela área selecionada em vermelho do diagrama:

Figura 8 - Influência dos fatores de risco na decisão

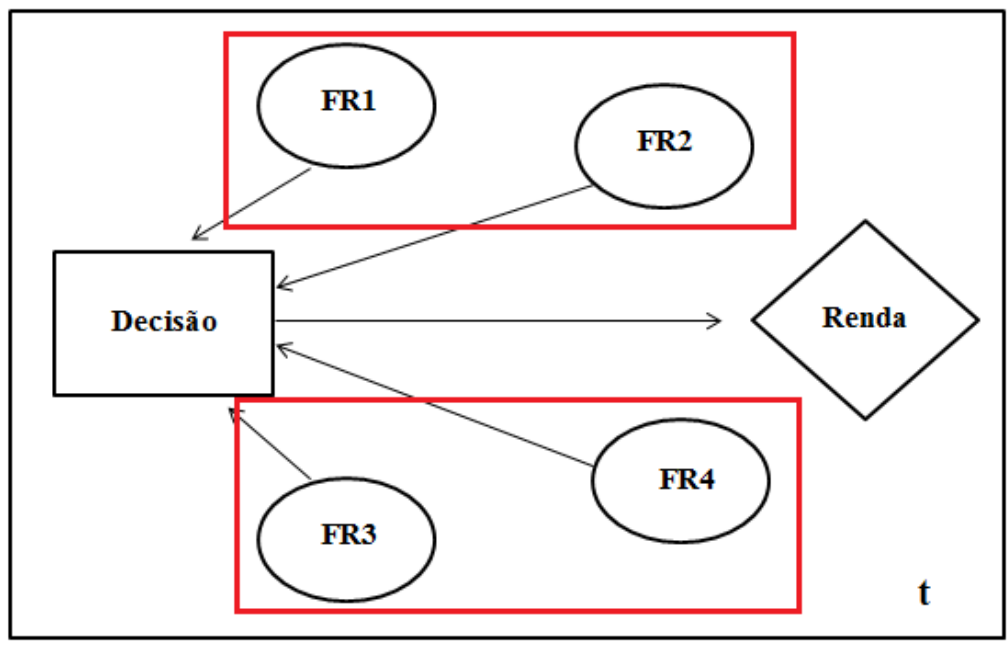

Fonte: $\mathrm{O}$ autor

Dessa forma, seu enunciado pode ser definido da seguinte forma:

\section{H2. O risco afeta a decisão do produtor direcionando-o a escolher arranjos institucionais de curto prazo.}

A teoria enumera os possíveis fatores geradores de risco aos quais os cafeicultores estão sujeitos, sendo assim pertinente identificar quais são de fato considerados na escolha contratual. Dado o processo de identificação desses fatores, será possível verificar o efeito marginal de cada fator sobre a escolha do cafeicultor. Como cada fator contribui para a decisão do cafeicultor?

A terceira hipótese a ser investigada relaciona como o produtor observa o ambiente institucional como facilitador para a mitigação do risco na qual as decisões estão embebidas. O ambiente institucional pode proporcionar a diluição do risco (proteção), de modo que os produtores optem por formas transacionais diferentes do mercado à vista? É preciso avaliar se o fator de risco preponderante para a decisão está ligado às variáveis de natureza institucional, como a reputação dos agentes e probabilidade do cumprimento do contrato. Dessa forma, as instituições podem baixar o prêmio de risco, tornando o contrato de longo prazo mais palatável. 
Conforme Zylbersztajn (1995), a forma como a quebra de contratos é conduzida gera impactos nas estratégias. North (1990) ressalta que se as "regras do jogo" não estiverem claras para os agentes o ambiente gerará risco, aumentando os custos de transação e elevando a importância das sanções econômicas. Quando as possibilidades de ganhos aumentam, em decorrência do comportamento oportunista, Klein (1992) argumenta que existem custos e benefícios em decorrência da quebra contratual. Cada agente avaliará se os ganhos serão menores que as sanções, legais ou econômicas. As sanções econômicas não são escritas no contrato, ganham importância, sobretudo nas próximas relações, dado o efeito reputacional. Em suma, essa questão envolve o seguinte enunciado:

H3. O ambiente institucional influencia o desenho dos contratos em geral e em particular a forma de transacionar o caféPara estudar as três hipóteses de pesquisa o método de análise é constituído de i) entrevistas in loco e ii) um modelo quantitativo, a seguir abordados. 


\section{MÉTODO}

Para responder às questões inerentes às hipóteses apresentadas, o método de análise é constituído de duas frentes: i) entrevistas com produtores; ii) modelo de simulação.

\subsection{Entrevistas Qualitativas}

A realização de entrevistas enquadra-se como uma abordagem qualitativa, sendo utilizadas para a coleta de dados na área de estudos organizacionais, como no campo das Ciências Sociais com ênfase nas áreas Jurídica, Contábil e da Administração por permitir a descrição e o aprofundamento sobre uma dada realidade social.

Segundo Yin e Fachin (2001), críticas direcionadas a esse método (bem como para estudos de caso) associadas à falta de objetividade de rigor não são exclusivas, pois podem estar presentes em outros métodos de investigação científica se o pesquisador não tiver treino ou as habilidades necessárias para realizar estudos de natureza científica. Este tipo de pesquisa caracteriza-se pelo estudo verticalizado, sendo objeto de observação uma empresa, uma instituição ou outro fenômeno. Na NEI o método é defendido por Lee Alston (1999) que sugere ser complementado aos métodos quantitativos.

Essa ferramenta pode ser indicada quando o pesquisador tem interesse em observar a ocorrência do fenômeno no campo social e discuti-lo conjuntamente sob o ponto de vista da teoria. Evidentemente, a teoria dialogará com o levantamento dos dados empíricos (os dados coletados no campo, observáveis na realidade) e na sua interpretação, mas o enfoque aqui é a construção da pesquisa com base em uma realidade delimitada.

Para o presente trabalho, foram realizadas entrevistas com o objetivo de identificar o comportamento dos produtores quanto à escolha por formas de transação do café, com foco na maneira como observam os fatores de risco associados a elas. Além disso, como a percepção do risco e o ambiente institucional influenciam as decisões sobre as diferentes formas de transação? 


\subsubsection{Região de interesse: Sul de Minas Gerais}

Segundo Martins (2010), Minas Gerais é o principal estado produtor de café no Brasil. O café, que adentrou o território mineiro nas primeiras décadas do século XIX pela Zona da Mata, espalhou-se pelo Sul de Minas a partir dos anos 1870. Gradativamente, o Sul de Minas tomou o lugar da Zona da Mata como principal área cafeicultora de Minas, deslocamento que se completou logo no decurso dos anos 1930. Quarenta anos depois, na esteira da "revolução verde" patrocinada pela ditadura militar, o café alcançou as áreas de cerrado no Alto Paranaíba. E, em fins da década de 1980, o café avançou sobre o Alto Jequitinhonha. Se, na virada do século XIX para o século XX, o café era o principal produto de exportação de Minas Gerais, ele é hoje a segunda mercadoria que mais gera divisas para o estado.

O café representa 70\% da renda agrícola do sul de Minas Gerais: Três Pontas, Guaxupé, São Sebastião do Paraíso, Varginha, São Tomás de Aquino, Itamogi, Alpinópolis e Santa Rita do Sapucaí são algumas das principais cidades. Muitas dessas surgiram a partir da construção das grandes fazendas, dado que a cafeicultura foi inserida na região na década de 1850 .

A região produz café arábica e a altitude média é de aproximadamente 950 metros. A média é de quatro mil cafeeiros por hectare, o que representa o sistema de cultivo semiadensado. Apesar dos terrenos topograficamente irregulares, os cafeicultores fazem uso da mecanização em suas lavouras. Quanto à irrigação, a tecnologia também vem sendo utilizada, haja vista que o regime hídrico-pluvial é também inconstante. Em janeiro de 2010 e 2011, o nível pluviométrico ficou abaixo da média e as chuvas foram mal distribuídas.

O grande entrave observado pelos produtores, entretanto, é o custo da mão de obra no Brasil vis-à-vis outros mercados, gerando perda de competitividade da cafeicultura nacional, especialmente das áreas tradicionais de montanha. Na cafeicultura, a mão de obra representa mais de $50 \%$ do custo de produção. Por conseguinte, segundo Vieira e Hafers (2010), a cafeicultura passa pelo mesmo desafio pelo qual passaram indústrias intensivas em mão de obra que, aos poucos, migraram de países ricos para países de menor renda. 
Assim, três produtores do sul do estado foram selecionados de modo a caracterizar a percepção dos fatores de risco.

\subsubsection{Visão geral dos procedimentos de campo}

Esta pesquisa parte da ideia de que a venda de entrega futura do café via contratos é uma escolha transacional preterida pelos produtores. As entrevistas foram realizadas de modo a qualificar, verificar e relacionar esse fato com a percepção de risco dos cafeicultores. Sua estrutura pode ser resumida no diagrama abaixo:

\section{Figura 9 - Visão geral das entrevistas qualitativas}

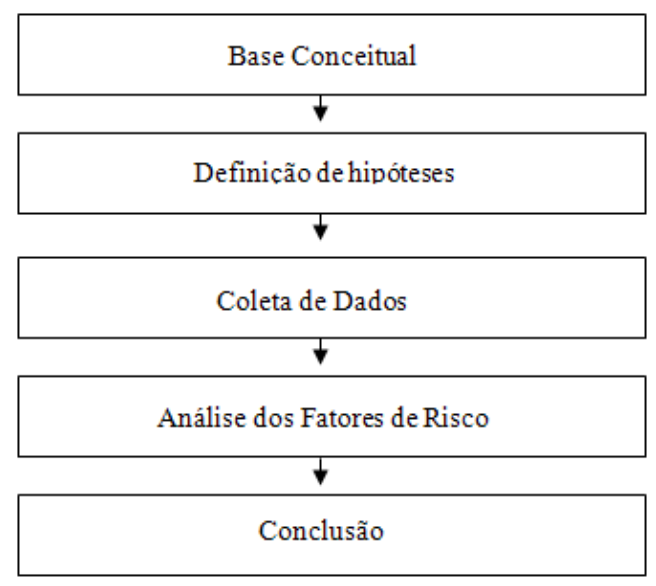

Fonte: O Autor

\subsubsection{Procedimentos iniciais}

Os procedimentos de campo iniciaram-se com o contato telefônico e eletrônico com os cafeicultores selecionados na base de contatos do grupo de pesquisa PENSA, da Universidade de São Paulo. Foram selecionados três produtores do sul de Minas Gerais, com os quais foram agendadas visitas presenciais. 
Entre 28 e 31 de março de 2012 foram realizadas visitas às instalações das lavouras, tomando lugar em seguida, as entrevistas qualitativas com seus responsáveis (proprietários). Seu conteúdo foi registrado em áudio, sendo esse disponibilizado em meio eletrônico.

\subsubsection{Roteiro para as entrevistas}

O roteiro básico com os pontos das entrevistas com produtores foi o seguinte:

1. Quais são os elementos de risco que os produtores destacam como influentes para sua atividade econômica?

2. Como a percepção desses fatores de risco influencia na decisão sobre a venda do café?

3. Qual o principal fator que os influencia a optar pelo mercado à vista?

4. Se houvesse o estabelecimento de um contrato que garantisse um intervalo de preço por diversos anos (dez, por exemplo), ele seria interessante?

5. Considerando que tal contrato implicaria relações de longo prazo, quais elementos, a priori, deveriam estar contidos em seu desenho, de forma a evitar quebras futuras?

6. Qual a influência da percepção do ambiente institucional sobre a decisão de transacionar o café?

Essas questões fornecerão respostas sobre com os cafeicultores percebem o risco e tomam suas decisões. O modelo de simulação a seguir descrito avaliará a decisão pela venda do café no mercado spot sob o ponto de vista da geração de renda. Esta escolha é a melhor sob tal aspecto em diferentes horizontes de tempo? 


\subsubsection{Descrição dos resultados}

O conteúdo resumido de cada entrevista será disponibilizado de acordo com os itens abaixo:

- Descrição básica da fazenda analisada

- Considerações sobre os custos como fator de risco.

- Considerações sobre o preço de café como fator de risco.

- Considerações sobre o clima como fator de risco.

- Posicionamento sobre a adoção de um contrato hipotético com travamento de preços

- Diagrama segundo o modelo analítico anteriormente apresentado.

As entrevistas embasam a análise da percepção de risco e a escolha transacional dos cafeicultores. O modelo de simulação, a seguir explanado, verifica a consistência temporal dessa escolha sob o ponto de vista da geração de renda.

\subsection{Modelo de Simulação}

O modelo de simulação foi construído com o objetivo de avaliar a renda do produtor obtida a partir do estabelecimento de um contrato hipotético de transação de venda do café. Feito isso, o resultado desse exercício foi comparado com a renda auferida de uma atuação estrita no mercado spot. Dessa forma, será possível avaliar o comportamento do produtor no mundo real, quanto à escolha pela venda do café a preços de mercado, sob a perspectiva da geração de renda. Tal contrato contém as seguintes características:

i. Tem como objeto de negociação distintas safras da produção do café. Assim, ele é travado por horizontes de tempo maiores do que um ano. 
ii. Limita a variação dos preços da saca: garante um preço mínimo e estipula um preço máximo.

iii. Pode ser estabelecido em conjunto com a atuação no mercado spot, ou seja, sua utilização não implica a total venda da safra mediante o preço vigente em contrato.

iv. Estipula um preço de negociação como segue:

a. Na data inicial são obtidas as propriedades estatísticas do preço da saca de café, olhando um horizonte de tempo de 6 meses. Portanto, obtém-se uma média e uma variância (desvio-padrão) para essa variável aleatória.

b. A partir disso constrói-se um intervalo composto pela média da distribuição, com um limite inferior de meio desvio-padrão e um superior de meio desvio-padrão (DP). Doravante, chamado aqui de intervalo de negociação.

c. A primeira transação de venda de café será feita 6 meses a partir da data inicial. Se o preço vigente estiver dentro do intervalo de negociação, a transação será travada pela sua média. Localizando-se abaixo do limite inferior, o preço a ser considerado é igual à média menos meio DP. Localizando-se acima do limite superior, o preço a ser considerado é igual à média mais meio DP.

Assim sendo, os procedimentos iniciais para essa análise incluem a construção da renda derivada do referido contrato. Para estes, é necessário também supor que envolvem a negociação de um café com alta especificidade, dado que eles são supostamente negociados com empresas torrefadoras que exigem uma lista de atributos prédeterminados. O primeiro passo consiste na definição de uma distribuição de probabilidades para o preço da saca de café. De acordo com Noronha e Latapia (1988), a sequência básica de cálculos para a realização de processos de simulação é a seguinte:

i. Definição da distribuição de probabilidade de cada uma das variáveis relevantes;

ii. Seleção ao acaso de um valor de cada variável, a partir de sua distribuição de probabilidade; 
iii. Fazer as operações matemáticas para obtenção do objeto de estudo com as amostras dos inputs do item anterior;

iv. Repetir o processo até que se obtenha uma confirmação adequada da distribuição de frequência do objeto escolhido para estudo.

Haja vista a impossibilidade de se estudar a distribuição de probabilidade de todas as variáveis pertinentes a uma questão complexa, a alternativa consistiu em identificar aquelas variáveis que exercem maior efeito sobre o resultado esperado do objeto de estudo. Embora existam, estatisticamente, vários tipos de distribuições de probabilidade, a tarefa de escolher a distribuição específica de uma determinada variável é difícil. Para a geração de valores simulados da renda do produtor proveniente do contrato hipotético, a variável de interesse será o preço da saca de café, modelada de acordo com funções de distribuição de probabilidade triangular. Em face da dificuldade envolvida na identificação das distribuições de probabilidade de cada uma das variáveis mais relevantes, é usual empregá-la. A distribuição triangular é definida por três parâmetros conhecidos: um nível médio ou moda (m), nível mínimo (a) e nível máximo (b). A função densidade de probabilidade é aquela que ao ser integrada fornece as probabilidades para a ocorrência de uma variável aleatória. A função de densidade de probabilidade triangular, por sua vez, (doravante FDT) assume a forma de um triângulo: a e b em cada extremo e m no centro:

\section{Gráfico 6 - Função de densidade de probabilidade triangular}

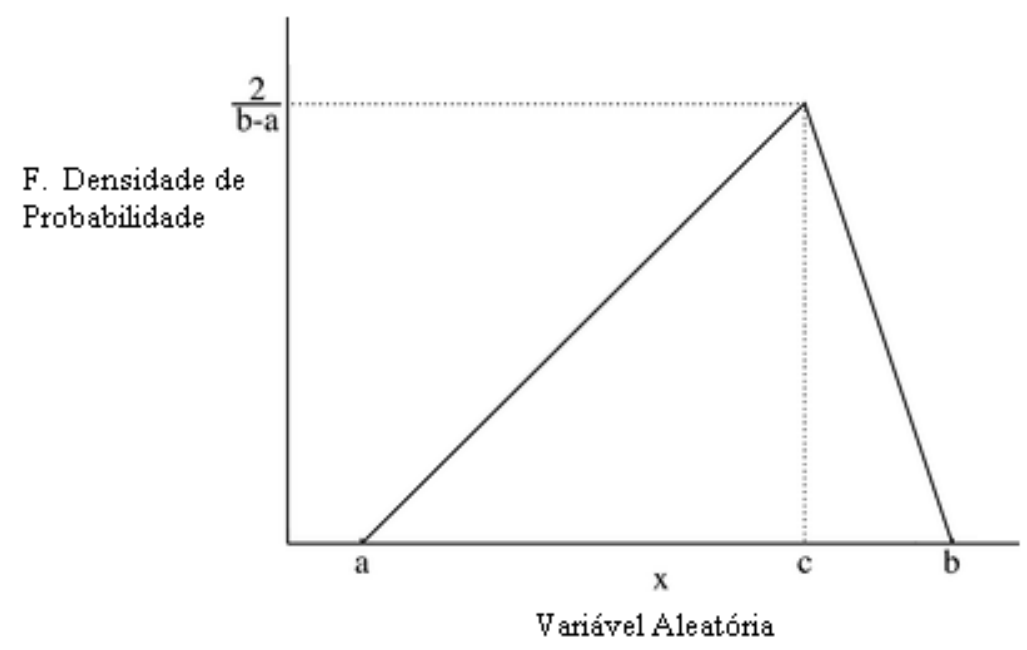

Fonte: Moretin (2003). 
Para a função de probabilidade acumulada, aquela que fornece as probabilidades do evento aleatório $\mathrm{X}$, a média e variância são dadas por:

$f(x \mid a, b, c)=\left\{\begin{array}{cc}\frac{2(x-a)}{(b-a)(c-a)} & a \leq x \leq c \\ \frac{2(b-x)}{(b-a)(b-c)} & c \leq x \leq b \\ 0 & \end{array}\right.$

Média: $\frac{a+b+c}{3} \quad$ Variância: $\frac{a^{2}+b^{2}+c^{2}-a b-a c-b c}{18}$

Seu gráfico assume a seguinte forma:

\section{Gráfico 7 - Função de densidade e probabilidade triangular}

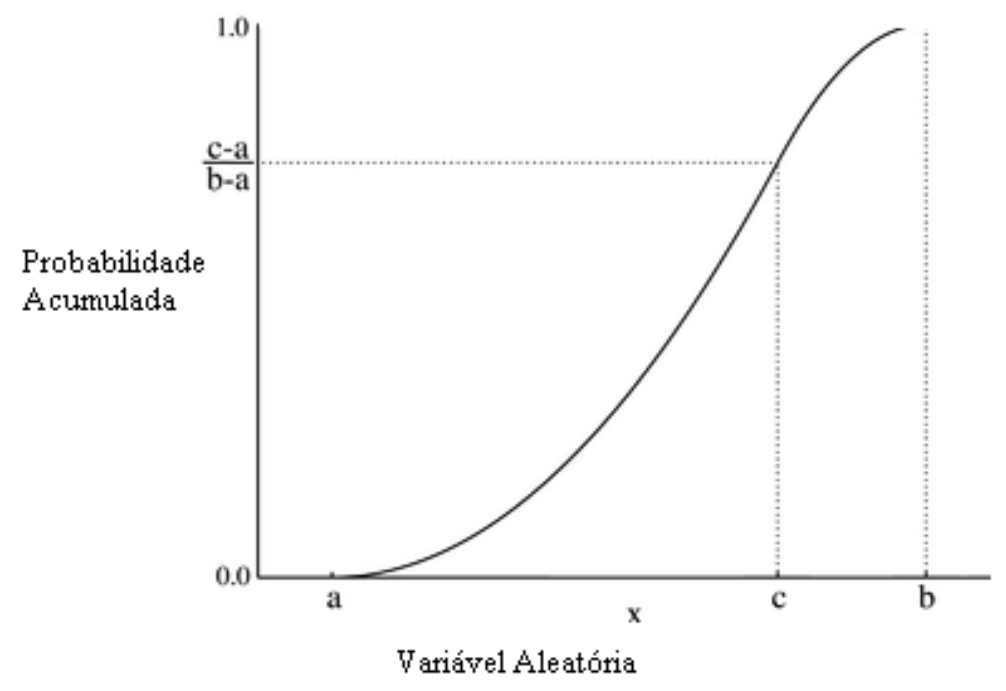

Fonte: Moretin (2003).

Considera-se o preço indicativo do café arábica da ESALQ/ CEPEA entre janeiro de 1995 e Julho de 2011. Deflaciona-se a série com a utilização do IPCA-IBGE. Dentro da janela de tempo estima-se uma função de distribuição triangular (FDT) para obter a flutuação dos preços dentro de prazo de seis meses. Assim sendo, cada um destes intervalos apresenta sua respectiva FDT. A construção da FDT para os preços observados do café apoiou-se na definição dos parâmetros: 


\section{Tabela 1 - Construção da FDT: Parâmetros}

\begin{tabular}{rr|}
\multicolumn{1}{c|}{ Parâmetro } & \multicolumn{1}{c|}{ Definição } \\
\hline Preço Médio (PM) & Média entre o Preço Final e Inicial \\
Preço Final (PF) & Maior preço entre o atual e o de 6 meses anteriores \\
Preço Inicial (PI) & Menor preço entre o atual e o de 6 meses anteriores \\
Amplitude (A) & Diferença entre Preço Final e Preço Inicial \\
Variabilidade (V) & Considera-se 50\% \\
\hline
\end{tabular}

Fonte: O Autor

Posto isso, o algoritmo para a obtenção da FDT obedece à lógica de construção descrita a seguir, com $\boldsymbol{p}$ representando valores aleatórios contidos no intervalo entre $[0 ; 1]$. Foi utilizado um algoritmo de geração de números pseudoaleatórios, devido a suas propriedades:

i. Seguem uma distribuição uniforme.

ii. Os números são estatisticamente independentes entre si.

iii. Os elementos não devem se repetir entre si.

iv. É operacionalmente viável.

Para a construção da FDT:

$\mathrm{Se}$

(i)

$\mathrm{Se}$

(ii)

Mediante 10 mil repetições desse processo, as FDT para os preços do café são estimadas. Para cada intervalo correspondente a um ano, uma FDT com o formato de um triângulo é estimada, cada intervalo considerado pode ser observado no gráfico a seguir: 


\section{Gráfico 8 - Funções Densidades de Probabilidades: Preços de Café}

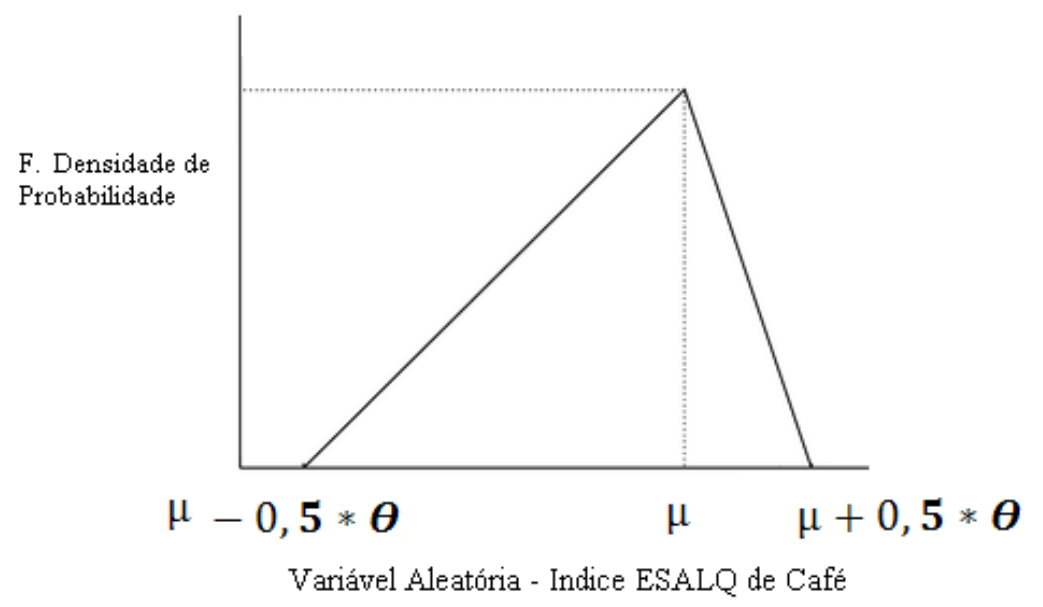

Fonte: $\mathrm{O}$ autor

O gráfico abaixo esboça a reunião das funções densidade de probabilidade triangulares para cada intervalo anual presente na simulação:

\section{Gráfico 9 - Funções Densidades de Probabilidades: Preços de Café}

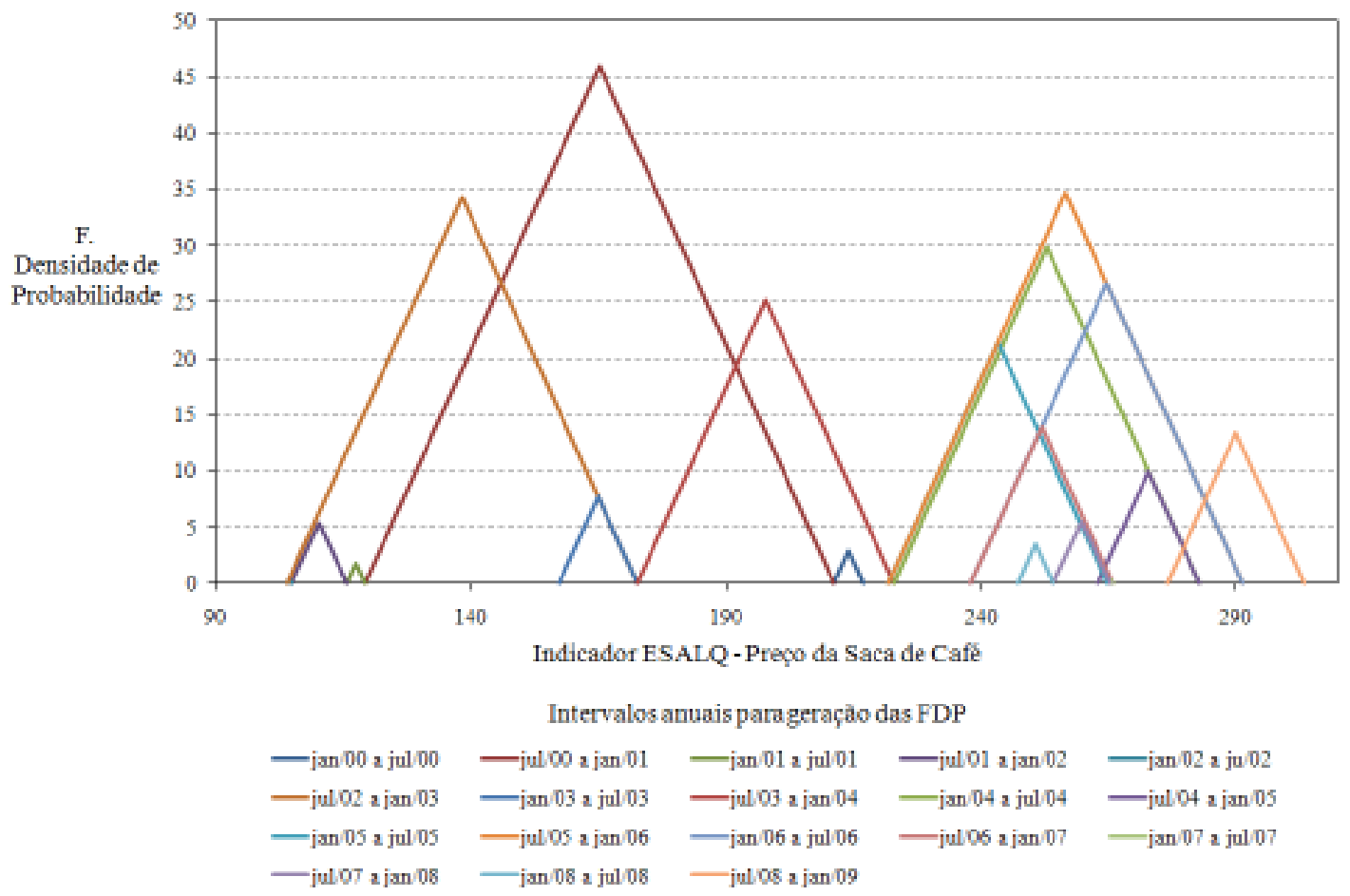

Fonte: O Autor. 
A renda é a receita obtida pela venda do café e é dada pela multiplicação do preço pela quantidade, subtraindo-se os custos de produção. Dado que o fato gerador de variabilidade para a renda será a variabilidade do preço, é preciso tecer as limitações do modelo proposto para as duas outras variáveis. Considerou-se uma condição simplificadora: os custos e as quantidades transacionadas são constantes. Dessa forma:

$R_{t}=P_{t} * Q_{t}-\mathrm{C}$

$\frac{\Delta R_{t}}{\Delta P_{t}}=\frac{\partial R_{t}}{\partial P_{t}} * Q$

A renda obtida no mercado spot ao longo do tempo será, portanto obtida pela seguinte expressão, na qual $\boldsymbol{P}_{\boldsymbol{t}}^{\boldsymbol{M}}$ representa o preço observado no indicador ESALQ.

$R_{t}=\sum_{t=1}^{N} \frac{P_{t}^{M}}{(1+r+w)^{t}}$

De forma análoga, a renda derivada do estabelecimento de um contrato com limite de variação de preços ao longo do período considerado será obtida pela expressão, na qual $\boldsymbol{P}_{\boldsymbol{t}}^{\boldsymbol{C}}$ representa o preço final determinado via contrato:

$R_{t}=\sum_{t=1}^{N} \frac{P_{t}^{C}}{(1+r+w)^{t}}$

A determinação de $\boldsymbol{P}_{\boldsymbol{t}}^{\boldsymbol{C}}$ depende do comportamento observado do preço de mercado $\boldsymbol{P}_{\boldsymbol{t}}^{\boldsymbol{M}}$ e dos momentos da distribuição triangular: da média $(\mu)$ e do desvio-padrão $(\theta)$ :

Se $\quad \boldsymbol{P}_{\boldsymbol{t}}^{\boldsymbol{M}}>\mu+0, \mathbf{5} * \boldsymbol{\theta}$ :

$R_{t}=\mu+0.5 * \theta$

Se $\quad P_{t}^{M}<\mu-0,5 * \boldsymbol{\theta}$ :

$R_{t}=\mu-0.5 * \theta$

Se $\quad \mu-\mathbf{0 , 5} * \boldsymbol{\theta}<\boldsymbol{P}_{\boldsymbol{t}}^{\boldsymbol{M}}<\mu+0.5 * \theta$ : 
$R_{t}=\mu$

A variável $\boldsymbol{r}$ é a taxa de juros pré-fixada no momento da data inicial do contrato e deverá ser empregada para trazer a valor presente as rendas obtidas pelas formas de transação. A variável $\boldsymbol{w}$ é o prêmio de risco associado à propensão ao risco do produtor. Será feita uma análise de sensibilidade para esse componente. Dessa forma, ele apresentará três possíveis valores:

i) Igual a $0,25 \%$, ou seja, considerando o produtor como avesso ao risco.

ii) Igual a - 0,25\%, ou seja, considerando o produtor como propenso ao risco.

iii) Igual a $0 \%$, ou seja, considerando o produtor como neutro ao risco.

Feito isso, é possível comparar a geração de renda da negociação via mercado spot com a de um contrato que limita a variação do preço futuro a ser recebido. Para o período entre 1995 e 2011, realizou-se a análise em três etapas:

i) Observando o período entre 1996 e 2001, ciclo de baixa do preço do café.

ii) Observando o período entre 2002 e 2011, ciclo de alta do preço do café.

iii) Observando a simulação para o período entre 1996 e 2011, considerando um período com um ciclo de baixa e um de alta do preço da saca do café.

Em suma, a regra de determinação do preço final e, portanto renda $R_{t}$, pelo qual o produtor vende seu produto segue o raciocínio ilustrado a seguir:

\section{Figura 10 - Funções Densidades de Probabilidades: Regra para geração da renda}

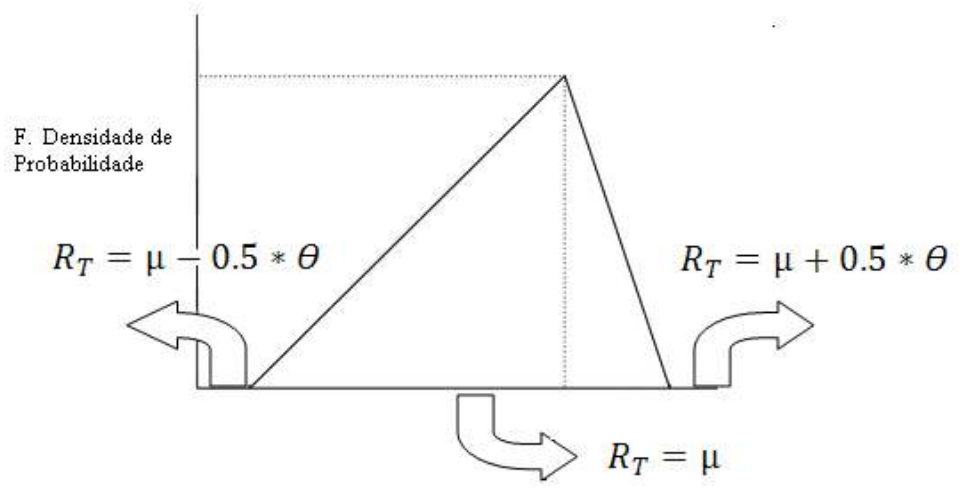

Fonte: $\mathrm{O}$ autor 
Com os resultados obtidos nos estudos de caso e no modelo de simulação, espera-se que as hipóteses possam ser discutidas à luz dos resultados e sujeitos às limitações que o modelo impõe. 


\section{RESULTADOS}

\subsection{Entrevistas qualitativas}

Foram visitadas três fazendas no sul do estado de Minas Gerais, de modo a investigar como seus produtores relacionam sua percepção de risco com sua atividade econômica. Para tanto, entrevistas abertas foram conduzidas com os proprietários das seguintes lavouras: Fazenda das Almas, Fazenda Passeio e Fazenda Três Pontas, localizadas respectivamente nos municípios de Cabo Verde, Alfenas e Três Pontas.

As entrevistas constituem ferramentas de análise para a coleta de evidências que esclareçam as hipóteses de trabalho lançadas. Buscou-se entender o comportamento dos produtores, considerando suas particularidades e o cenário no qual suas decisões se inserem. $\mathrm{O}$ cafeicultor, como tomador de decisão, torna-se, dessa forma, objeto central desse método de análise.

\subsubsection{Fazenda das Almas}

Localizada no município Cabo Verde, a fazenda apresenta uma produção de 90 hectares de café localizados em terrenos de encosta. Ela é responsável pela atração de uma população itinerante de aproximadamente 400 trabalhadores entre os meses de maio e julho, época de colheita.

Essa produção familiar, existente há três gerações, teve sua origem com a vinda de imigrantes portugueses. Com sua localização em morros, seus fundadores aproveitavam a altitude de suas instalações para rezar. Segundo a população local, o nome "das Almas" surgiu com a crença de que era possível escutar as vozes daqueles que já se foram.

Associados à Cooperativa Regional de Cafeicultores em Guaxupé (COOXUPÉ), parte da produção é separada e vendida para a Illy Café. Essa por sua vez, exige diversos requisitos e cuidados para que o grão seja negociado, garantindo um nível elevado para 
o café. Isso faz com o que o preço da saca seja diferenciado e acima do que o mercado normalmente pagaria, pois inclui uma margem que compense um maior custo marginal de produção.

Esse spread é benéfico ao produtor porque garante que seu produto encontrará mercado a um preço superior, desde que cumpra com todas as exigências demandadas durante o processo de produção. Entretanto, ele não pode destinar toda sua safra a esse nicho devido às condições intrínsecas do cafezal, pois nem todas as mudas germinarão grãos elegíveis.

Tanto a atuação nesse tipo de venda quanto naquela de entregue na cooperativa passa pela leitura que o produtor faz do risco da sua atividade. De forma objetiva, os fatores podem ser separados em dois grupos, os que afetam a demanda e os que incidem no lado da oferta.

Entre os fatores mencionados no lado da demanda, está o preço. No lado da oferta, as condições climáticas e os custos de produção, relacionados a seguir.

\subsubsection{Custos de Produção}

Segundo os proprietários da Fazenda das Almas, a cafeicultura em Cabo Verde está fadada a enfrentar crescentes dificuldades. A justificativa está nos custos de contratação da mão de obra e na perda de competitividade ante aqueles que já a mecanizaram. Representando em média $60 \%$ dos custos totais, a margem de lucro obtida pela fazenda é inferior àquelas já modernizadas. No caso específico das Almas, como as plantações são feitas em um terreno não plano, a dificuldade em se utilizarem ferramentas que superem as condições topográficas.

Nesse âmbito, há preocupação com o papel social dessa lavoura para o seu município. Esse fato sustenta a tradição pelo uso de mão de obra. Assim, gastos com melhorias nas condições de trabalho dos funcionários da fazenda vem sendo realizados. Na visita realizada foi possível conhecer as obras de dois refeitórios novos com áreas de descanso. 
O risco associado aos custos de mão de obra está ligado ao fato de a colheita ser boa ou não. Se houver algum tipo de praga ou incidente climático, parte da produção poderá ser perdida e a demanda pela força de trabalho cairá. Projetar custos por longos períodos de tempo torna-se uma tarefa árdua. Nesse quadro, o aspecto econômico influencia também os gastos com a folha de pagamento: a inflação e as leis trabalhistas podem encarecer ainda mais esse aspecto da produção.

Portanto, se não há como saber como se comportará o custo de produção, a margem da venda sobre os custos também estará numa área cinzenta. Trata-se de uma atividade com um dispêndio inicial alto e não há como saber quanto desses gastos serão remunerados e recuperados pela venda do grão final.

\subsubsection{Condições do clima}

A dependência das condições do clima reduz a flexibilidade do produtor em responder às flutuações dos mercados e coloca esse setor à mercê da imprevisibilidade do meioambiente. A incidência de chuva de pedra, intempérie que pode surgir durante qualquer época do ano, é mencionada como a principal preocupação dessa lavoura.

Em janeiro de 2012, produtores no sul de Minas Gerais, enfrentaram cinco chuvas de granizo em apenas um mês, atingindo 65 propriedades da região. Dentre essas houve perdas totais de agricultores. Para eventos desse cunho, existem seguros que se contratados podem limitar as perdas incorridas. Entretanto, conforme experiência dos cafeicultores da fazenda das Almas, a burocracia e o alto valor são entraves para o reparo dos danos financeiros oriundos de eventos climáticos.

O risco quanto a incidentes derivados do meio ambiente influi, portanto, no resultado dos produtores de café. 


\subsubsection{Sobre o preço da saca de café}

A indefinição quanto ao preço final da saca de café é relacionado como o principal agravante da projeção da margem de lucro. Segundo seu proprietário, o preço do café se comporta conforme os movimentos especulativos dos grandes fundos de investimento e, dessa forma, a oferta e procura por sacas de café ganham ponderação marginal em sua determinação.

Os preços das commodities respondem mais à especulação financeira que a demanda de países emergentes, como China e Índia. Em 2010, os contratos futuros de commodities movimentaram US\$ 63 bilhões formando um estoque, estimado pelo banco Barclays Capital, de US\$ 320 bilhões em apostas de que os preços continuarão subindo. Esse dado implica a intensificação de movimentos especulativos, mantendo os preços das commodities pressionados.

Dado isso, os contratos poderiam constituir num alternativa para que o produtor possa garantir determinado nível de preço para seu café.

\subsubsection{Sobre a adoção de contratos}

Os detalhes do contrato adotado no modelo de simulação foram apresentados ao produtor, sendo perguntado se esse seria interessante sob a ótica da mitigação do risco de mercado, da volatilidade do preço de café.

Um contrato que garantisse o preço do café seria certamente atrativo para os cafeicultores entrevistados em Cabo Verde. Dois aspectos hão de ser observados. O primeiro deles tangente à credibilidade da relação contratual. Para a Fazenda das Almas, a reputação da contraparte compradora seria o elemento primordial a ser considerado para a aceitação de um compromisso de entrega do café por diversos anos subsequentes.

Em segundo lugar, como sua função de custo detém uma variabilidade além da capacidade de previsão, mais importante que garantir o nível de preço é garantir a margem de lucro. Isso retiraria o produtor do "escuro" em relação à sua atividade e 
cobriria o seu risco de mercado. Para esses produtores, um contrato que definisse a margem de lucro seria uma relação atrativa.

Essas condições tornariam o contrato hipotético atrativo para o caso da fazenda das Almas. Observando o aparato institucional, é necessário pensar se o cumprimento dessa relação contratual encontraria respaldo no aparato institucional.

\subsubsection{Ambiente Institucional}

Considerando a eventual adoção do contrato hipotético, é possível garantir que ele seja honrado? O papel das instituições e das leis é reconhecido como fundamental para cumprimento de uma relação contratual nos moldes propostos. Existe, porém, um sentimento de desamparo por parte desses produtores, não sendo possível depositar expectativas em elementos do sistema judiciário como impeditivos ou inibidores de quebras contratuais.

Para a Fazenda das Almas, o componente essencial para a celebração das cláusulas de um contrato nesses moldes é a confiança mútua entre as partes. Se contraparte compradora do café detivesse, sob os olhos desses cafeicultores, reputação e credibilidade, a relação seria estabelecida e cumprida. Ainda que o preço à vista do café subisse acima de um limitador de alta, o acordo, por exemplo, seria honrado e o café entregue.

Para esse produtor, existe a percepção de que a cafeicultura adquiriu patamares rentáveis apenas recentemente. O relacionamento com uma contraparte garantisse margem de lucro, ainda que abaixo do mercado, deveria ser algo valorizado e perpetuado. Somente honrando as relações contratuais isso é possível. 


\subsubsection{Modelo analítico}

Relacionando os fatores de risco com a decisão sobre como vender o café, a figura abaixo retrata o modelo analítico aplicado para a Fazenda das Almas:

\section{Figura 11 - Fazenda das Almas}

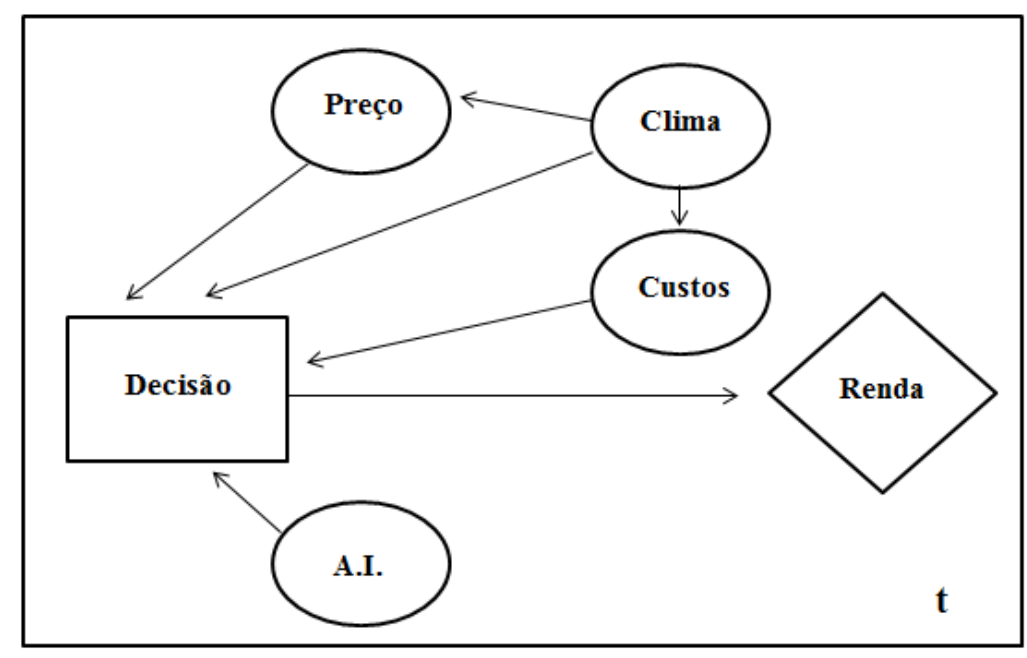

Fonte: O Autor

O fator de risco clima influencia diretamente custos de produção e o preço final porque dita se a safra será boa ou não. No limite, ela pode definir um cenário de escassez ou abundância da oferta de café. Para fazendas como a Passeio que dependem da contratação de mão de obra humana para a colheita, pode-se inferir que os custos possuem relação direta com flutuações do clima. Quanto melhor for a safra, ou seja, sem maiores entraves associados ao clima, maior será a demanda pelo trabalhador agrícola. Nesse sentido, o preço final da saca também será afetado, ainda que, conforme observado nas entrevistas, o produtor individual não tenha influencia sobre ele.

O ambiente institucional (A.I. na figura) incide na incerteza quanto ao cumprimento do contrato. Se o produtor sentir que a contraparte não detém reputação ou credibilidade, ele não acredita que as leis e os agentes do poder judiciário dariam respaldo à relação contratual.

Estes fatores de risco em conjunto direcionam o produtor a vender seu produto via mercado devido à priorização em obter um preço que seja superior ao seu custo de 
produção. Se a contraparte compradora do café detivesse credibilidade no cumprimento do contrato, o produtor certamente embarcaria na transação.

\subsubsection{Fazenda Passeio}

Localizada nas proximidades de Alfenas, a fazenda Passeio apresenta semelhanças com a Fazenda das Almas. Seus terrenos se encontram em solo irregulares e de altitude, variando entre 1100 e 1200 metros. Há também semelhanças entre a forma de pensar estrategicamente a produção, seus gargalos e perspectivas.

Dessa forma, a Passeio vem se especializando na produção de cafés especiais, entregando sua produção também em locais fora do Brasil. O manejo dos grãos é artesanal, com mão de obra treinada desde o preparo do solo até a fase final de colheita. A colheita é iniciada quando eles estão em estágio adiantado de maturação, de forma a eliminar grãos verdes e todo o processo de colheita é manual.

Dado todo o aparato e cuidado empregado na produção, a Passeio também atua vendendo seu produto para a Illy Café. Além disso, são realizados investimentos em certificações de sustentabilidade de modo a sinalizar ao mercado seu cuidado durante todas as etapas da produção de seus 170 hectares.

Associada a uma COOXUPÉ, essa lavoura se beneficia dessa aliança com o aprimoramento das técnicas empregadas mediante da interação junto de profissionais de conhecimento técnico. Dessa forma, a visão de risco guarda semelhança com o caso da lavoura da cidade de Cabo Verde. Os principais pontos da entrevista são mostrados a seguir. 


\subsubsection{Custos de Produção}

Os custos de produção concentram-se na contratação sazonal de mão de obra às vésperas da colheita. São contratados para os meses de maio a julho aproximadamente 130 funcionários que dispõe da estrutura interna da lavoura, sendo possível que residam em suas imediações. Esse atrativo se faz necessário para que esse perfil de trabalhador procure essa ocupação, dado que outros setores da economia os têm seduzido cada vez mais, de modo que o interesse pelo trabalho no campo é cada vez mais reduzido.

Outros custos, como aditivos orgânicos e adubos são também considerados relevantes na planta de custo dessa lavoura, entretanto, não são determinantes para as escolhas contratuais.

\subsubsection{Condições do clima}

Conforme grande parte das cidades do sul de Minas, a chuva de pedra representa a grande ameaça à plantação, dado seu caráter imprevisível ao longo de todos os meses do ano. A quebra que ela causa nas folhas das mudas faz com que o grão ainda verde caia e não possa ser aproveitado. O agravante do risco climático está na não entrega física do café e levando-se em conta a não disponibilidade de estoques, o produtor se vê numa situação de não cumprimento de suas relações e obrigações.

\subsubsection{Sobre o preço da saca de café}

"Nossa atividade é de alto risco", assim é definida a cafeicultura pelo proprietário da fazenda Passeio. A justificativa para esse comentário reside na incerteza do preço pelo qual o café será vendido, pois não existe qualquer garantia de que os custos para produzi-los sejam cobertos. 
Prevalece, também, a percepção de que os produtores não influenciam o comportamento dos preços de venda de seu produto. Os volumes financeiros movimentados por players do mercado especulativo são os determinantes dos movimentos mais bruscos desta commodity e o produtor nada pode fazer contra ou a favor deles. É possível apenas pensar na proteção de suas posições, como por exemplo, no mercado futuro.

Entre as commodities agrícolas produzidas no Brasil, a que apresenta maiores volatilidades de preço é o café (AGUIAR, 2004). Dada esta característica, operações de hedge com contratos futuros surgem como excelente alternativa para que cafeicultores reduzam seus riscos. Essa ferramenta, com a qual o diferencial entre o preço do contrato de entrega de café e o preço à vista é travado, é timidamente empregado pela fazenda Passeio.

\subsubsection{Sobre a adoção de contratos e o ambiente institucional}

Para a Fazenda Passeio, o contrato hipotético utilizado no modelo de simulação também seria uma modalidade atrativa de se negociar o café. Mesmo assim, o caráter incerto dos custos de produção ressalta que uma relação dessa natureza não funcionaria em horizontes muito longos. A Passeio acredita que contratos de entrega de café poderiam ser estabelecidos para no máximo até quatro anos.

Essa modalidade de contratos já foi adotada por essa empresa. Sob seu desenho, havia o estabelecimento de venda do café por determinado preço e a estipulação de determinadas características para que a venda seja feita. Entretanto, na época do cumprimento da relação, o preço da saca encontrava-se muito abaixo do valor acordado inicialmente. O produtor revela que as amostras enviadas para validação da qualidade do café eram rejeitadas e desta forma a venda não era feita devido a seu custo de mensuração elevado.

É destacado que o contrato deve ser estabelecido apenas com um grupo seleto de produtores e empresas. Semelhante à fazenda das Almas, o cumprimento efetivo do acordo estaria associado à reputação dos agentes. Se o mercado os enxerga com credibilidade, os contratos ganharão incentivos para serem estabelecidos e honrados. 
Portanto, o efeito reputacional seria o elemento motivador do surgimento das relações contratuais de limitação de preço na cafeicultura.

Note-se, também, que o atrativo maior do contrato hipotético seria para esse produtor, a garantia de uma margem de lucro sobre o custo de produção, mesmo que seja mínima. Nesse sentido, o incentivo de quebra contratual de sua parte seria ignorado, independente do preço de mercado ser superior ao acordado.

Para essa lavoura, em face de incentivos para o não cumprimento dos contratos de entrega do café, o aparato institucional não seria sólido o suficiente para que eles se "fizessem valer". Portanto, ele também se enquadra como um fator de risco para que a adoção de relações dessa natureza sejam estabelecidas.

\subsubsection{Modelo analítico}

Para a Fazenda Passeio, o modelo analítico apresenta o seguinte desenho:

Figura 12 - Fazenda Passeio

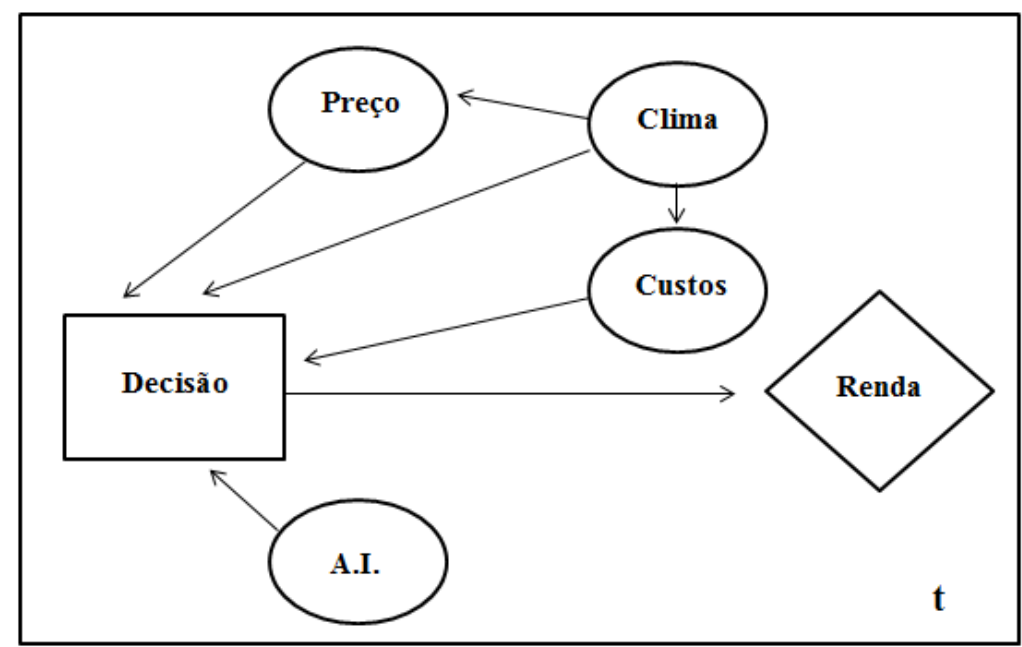

Fonte: O Autor

O fator de risco clima influencia custos de produção e o preço final porque pode ditar se a safra será boa ou não. Dessa forma, ela pode definir a escassez ou abundância da 
oferta de café. Quanto melhor for a safra, ou seja, sem maiores entraves associados ao clima, maior será a demanda pelo trabalhador agrícola.

Por mais que o preço final da saca seja definido pelo movimento de grandes players do mercado financeiro e o produtor individual não tenha influencia sobre ele. $\mathrm{O}$ ambiente institucional incide na incerteza quanto o cumprimento do contrato. Se o produtor sentir que a contraparte não detém reputação ou credibilidade, ele não acredita que as leis e os agentes do poder judiciário dariam respaldo à relação contratual.

Esses fatores de risco em conjunto influenciam a escolha do produtor sobre como vender seu produto.

\subsubsection{Fazenda Três Pontas}

Três Pontas é um município, a menos de $50 \mathrm{~km}$ der Varginha e seu clima ameno propicia o cultivo do café, sua maior riqueza econômica. Essa cultura desenvolveu-se na região no início do século XX e hoje agrupa de 30 milhões de cafeeiros plantados, numa área de 24.000 hectares.

Essa lavoura abrange uma área de 270 hectares para a produção do café numa área de planalto. O cultivo da região incorporou sofisticadas pesquisas agronômicas e se tornou um negócio de alta tecnologia. A área é caracterizada por duas grandes fazendas e uma de porte médio. O café é plantado em filas ou "renques" para permitir o cultivo e a colheita mecanizados.

Cerca de $80 \%$ da produção é comercializado pela Cooperativa dos Cafeicultores da Zona de Três Pontas (COCATREL) o restante é destinado ao mercado. O mercado de cafés especiais ainda não faz parte de seu nicho de atuação. A fazenda pretende começar a fornecer seus grãos para empresas que exigem esse café de qualidade. Para isso investe em melhorias no processo produtivo, bem como na obtenção de certificações de sustentabilidade da lavoura.

Ressalte-se que produzir cafés especiais não é tarefa fácil. Os custos são mais elevados e a influência climática é ainda mais decisiva, de modo que os produtores também não 
podem abdicar de produzir grãos mais inferiores. Afinal, o caixa precisa ser fechado no fim do mês. "Mas o importante é entrar no negócio", afirma Jorge, dono da lavoura. A percepção dos fatores de risco e algumas práticas dos produtores dessa lavoura se distanciam das duas já descritas anteriormente.

\subsubsection{Custos de Produção}

Em contraste com as outras duas lavouras visitadas, a mecanização está presente no processo de produção e a contratação de excedente sazonal de mão de obra humana não é necessária. A consequência desse fato, segundo o proprietário da lavoura, é uma função de custo que oscila menos, sendo assim de projeção mais fácil. Ela é observável em horizontes de tempo maiores, pois eles englobam em sua maioria: manutenção, depreciação e manuseio dos equipamentos empregados.

Portanto, variações que alterem a curva de custo não estão associadas a outros fatores de risco, como incidentes do clima ou choques de demanda.

Hoje a fazenda conta com 20 funcionários apenas e dada uma topografia privilegiada, é possível que diversas técnicas sejam empregadas com o auxílio de máquinas. Dessa forma, os custos de produção não constituem um fator de risco para a produção da fazenda Três Pontas.

\subsubsection{Sobre o preço da saca de café}

A fazenda já atuou no mercado futuro montando suas posições de hedge, entretanto, a cultura da preterir esses instrumentos prevaleceu com o abandono do uso de derivativos. Estes produtores acreditam que essa realidade está distante de ser observada, dado que o café tornou-se objeto de especulação dos mercados financeiros. 


\subsubsection{Condições do clima}

A influência do clima também é apontada como um fator de risco para a produção. A chuva de pedra e a geada foram as intempéries mencionadas, podendo aparecer durante $\mathrm{o}$ ano inteiro, produtores já foram castigados às vésperas da colheita.

Sob a ação da força da natureza pouco se pode atuar e o seguro rural é descrito como burocrático e complicado em demasia. Para que o pagamento de eventos de perdas seja feito, é exigido que a lavoura seja destruída por inteira. Dado que frequentemente não é o que acontece, seu cafeicultor prefere abrir mão do uso de seguro. O baixo relevo da região permite que as mudas não sejam tão afetadas como aconteceria numa fazenda de encosta.

$\mathrm{O}$ ataque de pragas também pode trazer preocupações para o bom desempenho de uma safra, mas é considerado controlável mediante o uso de instrumentos como pesticidas.

\subsubsection{Sobre a adoção de contratos e o ambiente institucional}

Quanto à utilização de contatos que travam o preço, eles seriam interessantes não apenas dentro de horizontes de tempo mais curtos, diferentemente das demais analisadas. Haja vista que os custos podem ser projetados em horizontes de tempo mais longos, o risco quanto à margem de lucro passa a recair sobre os preços.

Desse modo, o contrato poderá ser desenhado de modo a limitar o preço de venda do café. Uma vez definida essa variável, a projeção da margem do lucro poderia ser feita de forma bastante acurada. A ideia de que a magnitude da margem é secundária ante o fato de ela ser positiva também impera também para este produtor.

Considerando que a produção de café apresentou em diversos momentos prejuízo, é imperativo para o cafeicultor que sua produção cubra seus custos. Lucros extraordinários seriam eventos momentâneos, não uma tendência perene. 
A burocracia seria um entrave para que os contratos fossem estabelecidos, dado que as contrapartes envolvidas na transação necessitam se conhecer a fundo para que compromissos nos moldes mencionados fossem feitos.

\subsubsection{Modelo Analítico}

Relacionando os fatores de risco com a decisão sobre como vender o café, o modelo analítico abaixo é obtido para a fazenda Três Pontas:

\section{Figura13 - Fazenda Três Pontas}

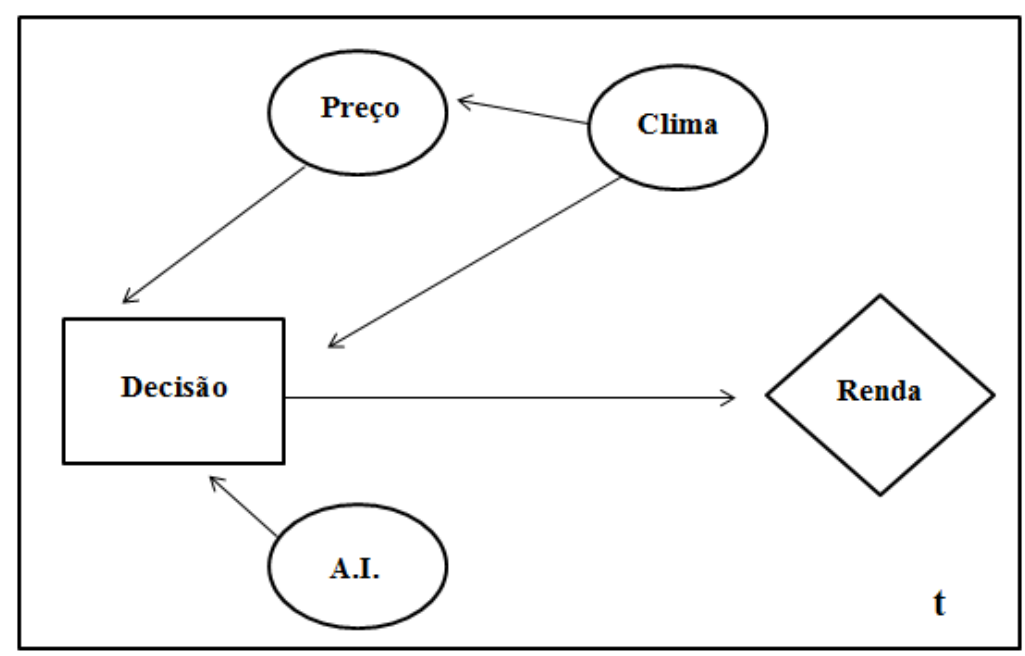

Fonte: O Autor

O clima atinge o resultado da safra em termos de quantidade e de qualidade e, assim, exerce influência direta no preço final da saca, ainda que os grandes fundos de investimento sejam os determinantes da volatilidade no preço dessa commodity. Dado que os custos estão ligados à mecanização da lavoura, eventos climáticos não afetam os custos da fazenda Três Pontas. O ambiente institucional (A.I. na figura) incide no risco do não cumprimento do contrato. Se o produtor sentir que a contraparte não detém reputação ou credibilidade, o produtor não acredita que os incentivos à quebra contratual serão ignorados e o compromisso honrado. Esses fatores de risco em 
conjunto influenciam a forma como o produtor decidirá vender seu produto e, portanto na renda auferida.

A preocupação quanto a margem de lucro recai sobre o risco do preço, dado que os custos desta lavoura são independentes do desempenho da colheita. Desta forma, essa fazenda estaria disposta a travar contratos de maior duração que as demais analisadas, desde que pudesse estipular o preço de venda para seu produto.

\subsection{Modelo de Simulação}

No presente item são apresentados os resultados extraídos do modelo de simulação. O objetivo aqui é comparar as rendas obtidas nos diferentes arranjos institucionais ao longo dos períodos de tempo selecionados. Considerando-se a série histórica do indicador do preço da saca de café ESALQ, entre 1995 e 2011, o modelo de simulação de renda foi construído em três etapas. Primeiro dividiu-se a série temporal em duas partes, para depois olhá-la por inteiro:

iv) Entre 1996 e 2001, período com um ciclo de baixa do preço do café.

v) Entre 2002 e 2011, período com um ciclo de alta do preço do café.

vi) Entre 1996 e 2011, período considerando ambos os ciclos.

Para cada etapa, foram simulados diferentes arranjos institucionais e as respectivas rendas que os produtores obteriam. Dado o trade-off entre vender no mercado spot ou via contrato, para cada uma delas foi calculado o resultado para diferentes percentuais de alocação entre a venda via contrato e mercado spot:
vii) $\quad 100-0 \%$
viii) $\quad 50-50 \%$
ix) $\quad 30-70 \%$ 
Os resultados da simulação são obtidos pelos passos anteriormente descritos, cuja implementação é ilustrada a seguir:

Tabela 2 - Resultados da Simulação

\begin{tabular}{|c|c|c|c|c|c|c|}
\hline Mínino & 212,9131477 & \begin{tabular}{|l|}
207,1331477 \\
\end{tabular} & 54,10147337 & 242,271737 & 226,4192753 & 257,6547225 \\
\hline Máximo & 215,3070772 & 221,0870772 & 276,3021081 & 259,0985343 & 297,3718683 & 322,3063196 \\
\hline Média & 214,5416121 & \begin{tabular}{|l|}
214,1353946 \\
\end{tabular} & 165,6043806 & 250,7156229 & 262,0241259 & 290,0976587 \\
\hline Índice de Preço & & 119,18 & 115,53 & 276,59 & 303,37 & 410,77 \\
\hline DP da FDP & 0,724227959 & 6,426653853 & 102,3372354 & 7,749788469 & 32,6780894 & 29,77608827 \\
\hline Renda: Alocação 100\% C & & 213,82 & 207,71 & 247,44 & 258,47 & 294,70 \\
\hline Renda: Alocação 50-50 C & & 106,91 & 103,85 & 247,32 & 267,53 & 299,04 \\
\hline Renda: Alocação 30-70 C & & 64,15 & 62,31 & 247,27 & 271,15 & 300,77 \\
\hline Data inicial da safra & $2000-07-03$ & 2001-01-03 & & & 2010-07-05 & $2010-12-28$ \\
\hline$\# 1$ & 215,2057293 & 220,9857293 & & & 296,8565373 & 321,8367529 \\
\hline$\# 2$ & 215,014232 & 220,794232 & & & 295,8828163 & 320,949504 \\
\hline$\# 3$ & 214,8206507 & 220,6006507 & & . & 294,8984988 & 320,0525994 \\
\hline$\# 4$ & 213,1265922 & 207,3465922 & & . & 227,5045925 & 258,6436572 \\
\hline \#5 & 213,4220997 & 207,6420997 & & & 229,0071819 & 260,0128082 \\
\hline . & & 207,6742333 & 62,7176532 & 242,9242225 & 229,170574 & \\
\hline . & & 220,6611065 & 269,5190046 & 258,5848638 & 295,2059034 & \\
\hline$\cdot$ & & 207,6374141 & 62,13134804 & 242,8798229 & 228,9833564 & \\
\hline$\# 10000$ & 215,2202399 & 221,0002399 & 274,9193226 & 258,9938188 & 296,9303204 & 321,9039837 \\
\hline
\end{tabular}

Fonte: O Autor

As colunas iniciais da esquerda mostram as variáveis e os parâmetros empregados na simulação: Mínimo, Máximo, Média, Índice de Preço e DP da FDP (desvio-padrão da função densidade de probabilidade) são utilizados para a construção das FDT. Os campos "Renda: Alocação" trazem a renda simulada para cada arranjo institucional proposto, com a variação da proporção entre a negociação do café entre mercado e contrato. Esse exercício é repetido 10 mil vezes para os ciclos de alta e de baixa, bem como o período consolidado.

Os processos de simulação embora estejam voltados para a verificação da renda adotam um pressuposto forte: o da não inclusão da variação das quantidades de sacas negociadas. É assumido que o comportamento da demanda permanece estável ao longo dos anos de análise. 
A primeira justificativa para essa adoção está no componente operacional do método de simulação, a complexidade de simular preço e quantidade conjuntamente para três séries temporais e três percentuais de alocação seria um entrave considerável. Em segundo, o café é um produto estocável. Se a demanda está contraída em determinado ano, é possível guardar a produção de uma colheita e vendê-la num período seguinte. Dado que o interesse aqui é para o resultado de uma relação contratual de longo prazo, os efeitos de se estocar o café de uma colheita e negociá-lo em qualquer safra posterior seriam marginais. Em terceiro, a demanda por café historicamente mantém um patamar estável. Sob a ótica do risco, dos fatores que representam alguma ameaça à atividade do produtor, a procura por café não parece ser algo relevante. Isso também pôde ser verificado nas entrevistas realizadas, uma vez que, em nenhum momento, os produtores mencionaram a demanda como fator de risco.

Dessa forma, ao considerar apenas os efeitos da volatilidade do preço do café para a apuração do resultado da venda do café se extrai um resultado centralizado no que o produtor pondera como risco. Os resultados da simulação serão comparados:

i) Com a renda obtida da venda de $100 \%$ pelo preço de mercado, com o indicador:

$\%$ acima do mercado $=\frac{\text { renda simulada do arranjo institucional }}{\text { renda obtida a atuação no mercado spot }}-1$

ii) Com o valor médio do indicador do preço de café (ESALQ) para os prazos indicados, com o indicador:

$\%$ acima da média $=\frac{\text { renda simulada do arranjo institucional }}{\text { média do indicador de preço ESALQ }}-1$

Dois conjuntos de coeficientes para cada uma das três etapas de simulação foram produzidos. O primeiro indicador mostra o quanto melhor ou pior (em percentual) é a escolha por contrato em relação à venda estrita no mercado. O segundo compara a renda auferida no contrato com o comportamento médio do indicador de preço.

Os indicadores têm a finalidade de identificar qual alocação é superior, dados os diferentes percentuais de alocação mercado/ contrato, se eles obteriam melhores resultados do que a venda e $100 \%$ do café no mercado à vista. 


\subsubsection{Período entre 1996 e 2001 - Ciclo de baixa}

Os resultados do processo de simulação para esse período foram os seguintes:

Tabela 3 - Renda Simulada para o Período entre 1996 - 2001

\begin{tabular}{|crcc|}
\hline Proporção entre contrato/ mercado & Renda Simulada & \% acima do mercado & \% acima da média \\
\hline $100-0 \%$ & $1.461,61$ & $0,24 \%$ & $0,20 \%$ \\
\hline $50-50 \%$ & $1.470,11$ & $0,83 \%$ & $0,67 \%$ \\
\hline $30-70 \%$ & $1.473,51$ & $1,06 \%$ & $0,86 \%$ \\
\hline $0-100 \%$ & $1.458,05$ & - & - \\
\hline
\end{tabular}

Fonte: O Autor

Para o período considerado como ciclo de baixa, os dois conjuntos de coeficientes mostraram que um contrato misto de alocação é superior à atuação estrita no mercado à vista. Notou-se que quanto maior é a alocação no mercado, maior é o valor da renda simulada.

Assim, o modelo 30-70\% é superior às outras configurações. É interessante observar que a escolha mercado/ contrato embora sempre superior, ganha uma tendência crescente conforme o uso do mercado é maior. A venda do café fora do mercado, com a adoção de contratos, pode representar ganhos para o produtor, mas, para garantir o maior nível de renda a venda, não deve ser feita exclusiva via a utilização de contratos.

Quanto à configuração superior nessa janela de análise, a 30-70\%, ela corrobora uma tendência observada nas visitas aos cafeicultores. A demanda por entrega de café por parte de empresas processadoras ou torrefadoras não correspondem a produção total de uma lavoura. Dessa forma, o resultado da simulação aponta que esa alocação é consistente sob a óptica da geração de renda, em períodos de baixa para a saca de café. 


\subsubsection{Período entre 2002 e 2011 - Ciclo de alta}

Os resultados do processo de simulação para o período mencionado foram os seguintes:

Tabela 4 - Renda Simulada para o Período entre 2002 - 2011

\begin{tabular}{|crcc|}
\hline Proporção entre contrato/ mercado & Renda Simulada & \% acima do mercado & \% acima da média \\
\hline $100-0 \%$ & $3.954,56$ & $-3,30 \%$ & $-2,78 \%$ \\
\hline $50-50 \%$ & $4.021,98$ & $-1,65 \%$ & $-1,39 \%$ \\
\hline $30-70 \%$ & $4.048,95$ & $-0,99 \%$ & $-0,84 \%$ \\
\hline $0-100 \%$ & $4.089,40$ & - & \\
\hline
\end{tabular}

Fonte: O Autor

Para o período considerado como ciclo de alta, os dois conjuntos de coeficientes mostraram que a escolha de um contrato misto de alocação seria inferior em relação à atuação estrita no mercado à vista. De forma semelhante, notou-se que quanto maior é a alocação no mercado, maior é o valor da renda simulada.

A alocação contrato/ mercado em 30-70\% também apresenta superioridade em relação às outras duas, ainda que não tenha sido superior a escolha pela venda estrita no mercado.

\subsubsection{Período entre 1996 e 2011 - Ciclos de baixa e alta}

Os resultados do processo de simulação para o período mencionado estão resumidos no quadro abaixo:

Tabela 5 - Renda Simulada para o Período entre 1996 - 2011

\begin{tabular}{|crcc|}
\hline Proporção entre contrato/ mercado & Renda Simulada & \% acima do mercado & \% acima da média \\
\hline $100-0 \%$ & $5.416,16$ & $-2,37 \%$ & $-2,58 \%$ \\
\hline $50-50 \%$ & $5.492,09$ & $-1,00 \%$ & $-1,08 \%$ \\
\hline $30-70 \%$ & $5.522,46$ & $-0,45 \%$ & $-0,49 \%$ \\
\hline $0-100 \%$ & $5.547,46$ & - & - \\
\hline
\end{tabular}

Para o período que contempla os dois ciclos, ambos os conjuntos de coeficientes mostraram inferioridade de um contrato misto de alocação em relação à atuação estrita no mercado à vista. Se comparada com a renda obtida na venda no mercado spot, a renda simulada para contratos que vendam parte da produção do mercado e parte da 
produção via um contrato com limitador de preço foi menor para todos os níveis de alocação.

Em primeiro lugar isso se deve ao fato de o período de baixa apresentar um número de anos (6) menor que o ciclo de alta (10). A união dos resultados dessas duas janelas de tempo tende a ponderar mais fortemente a renda obtida no ciclo de alta.

Em segundo, o período definido como o ciclo de alta apresentou níveis historicamente nunca vistos, de modo que qualquer outra modalidade de contrato seria inferior aos ganhos no mercado spot. Dessa forma, a conclusão com os resultados do período de alta é a mesma, entretanto, como nessa análise são contemplados também os anos do ciclo de baixa, observou-se que a superioridade em relação à venda estrita no mercado sofreu uma queda (coluna Variação no quadro abaixo):

\section{Tabela 6 - Comparação entre o Ciclo de Alta e o período completo}

\begin{tabular}{cccc|} 
Proporção entre contrato/ mercado & Ciclo de Alta & Ambos os Ciclos & Variação \\
\hline $100-0 \%$ & $-3,30 \%$ & $-2,37 \%$ & $-28,23 \%$ \\
\hline $50-50 \%$ & $-1,65 \%$ & $-1,00 \%$ & $-39,46 \%$ \\
\hline $30-70 \%$ & $-0,99 \%$ & $-0,45 \%$ & $-54,44 \%$ \\
\hline
\end{tabular}

Fonte: O Autor

Foi possível, dessa forma, detectar uma tendência de perda da força da escolha pela venda exclusiva no mercado à vista.

Novamente, quanto maior a alocação no mercado, maior o valor da renda simulada. A configuração $30-70 \%$ apresenta superioridade em relação às outras duas, ainda que não seja superior à escolha pelo venda estrita no mercado.

Portanto, para o período completo de análise, a escolha pelo mercado seria a melhor considerando a renda derivada da venda no mercado à vista. $\mathrm{O}$ resultado perde força se comparado com a análise de um período com forte apreciação da saca de café (ciclo de alta). 
Considerando o efeito dos ciclos de anos de forte alta na análise e se levado em conta resultados não financeiros no estabelecimento de contratos, é possível afirmar que a superioridade pela escolha via mercado existe, mas é fracamente superior.

Nos itens a seguir, serão reportados os resultados das análises marginais, nas quais foram alterados parâmetros dos modelos para que pudessem ser observados os reflexos nos resultados da simulação dos contratos hipotéticos durante os ciclos de alta e baixa.

\subsection{Variação do prêmio de risco}

Os resultados descritos anteriormente foram obtidos pela utilização da taxa de juros livre de risco, desconsiderando o prêmio associado à propensão ao risco. Assim sendo, conforme apresentado nesse item, simulou-se também o desconto a valor presente, com o acréscimo de um prêmio de risco, equivalente a:

i) $\quad 0,25 \%$, para o caso de aversão ao risco.

ii) $\quad-0,25 \%$ para o caso de propensão ao risco.

Os resultados obtidos são expressos a seguir:

Tabela 7 - Ciclo de Alta - Aversão ao risco

\begin{tabular}{|ccc|}
\hline Proporção entre contrato/ mercado & Renda Simulada & \% acima do mercado \\
\hline $100-0 \%$ & $3.827,74$ & $-5,55 \%$ \\
\hline $50-50 \%$ & $3.940,24$ & $-2,78 \%$ \\
\hline $30-70 \%$ & $3.985,23$ & $-1,67 \%$ \\
\hline $0-100 \%$ & $4.052,73$ & - \\
\hline
\end{tabular}

Fonte: O Autor

Tabela 8 - Ciclo de Alta - Propensão ao risco

\begin{tabular}{|crc|}
\hline Proporção entre contrato/ mercado & Renda Simulada & \% acima do mercado \\
\hline $100-0 \%$ & $3.879,94$ & $-5,55 \%$ \\
\hline $50-50 \%$ & $3.993,97$ & $-2,78 \%$ \\
\hline $30-70 \%$ & $4.039,58$ & $-1,67 \%$ \\
\hline $0-100 \%$ & $4.107,99$ & - \\
\hline
\end{tabular}

Fonte: O Autor 
Conforme as tabelas anteriores mostram, para o ciclo de alta, a renda derivada dos contratos foi inferior à renda da atuação no mercado, de modo que os indicadores mostram uma superioridade mais acentuada que aqueles que consideram apenas a taxa livre de risco para o desconto intertemporal. Não há distinção entre a propensão ao risco e aversão ao risco no tocante aos indicadores, entretanto, a renda simulada para o agente propenso ao risco é menor, devido a um fator de desconto superior ao do avesso.

Foi feita a mesma analise para o ciclo de baixa, cujos resultados são mostrados a seguir:

Tabela 9 - Ciclo de Baixa - Aversão ao risco

\begin{tabular}{ccc|} 
Proporção entre contrato/ mercado & Renda Simulada & \% acima do mercado \\
\hline $100-0 \%$ & $1.461,23$ & $0,672 \%$ \\
\hline $50-50 \%$ & $1.466,59$ & $1,041 \%$ \\
\hline $30-70 \%$ & $1.468,73$ & $1,188 \%$ \\
\hline $0-100 \%$ & $1.451,49$ & - \\
\hline
\end{tabular}

Fonte: O Autor

Tabela 10 - Ciclo de Baixa - Propensão ao risco

\begin{tabular}{ccc|} 
Proporção entre contrato/ mercado & Renda Simulada & \% acima do mercado \\
\hline $100-0 \%$ & $1.474,52$ & $0,672 \%$ \\
\hline $50-50 \%$ & $1.479,92$ & $1,041 \%$ \\
\hline $30-70 \%$ & $1.482,08$ & $1,188 \%$ \\
\hline $0-100 \%$ & $1.464,68$ & - \\
\hline
\end{tabular}

Fonte: O Autor

Conforme as tabelas anteriores mostram, para o ciclo de baixa, a renda derivada dos contratos foi superior à renda da atuação no mercado. Essa superioridade tornou-se mais acentuada mediante a incorporação dos prêmios de risco, dado que a primeira análise utilizou desconto intertemporal apenas com a taxa de juros livre de risco.

\subsection{Variação do parâmetro de variabilidade}

Simularam-se também os resultados advindos da alteração do parâmetro de variabilidade utilizado na construção da função triangular de distribuição de 
probabilidade. Considerou-se $35 \%$ ao invés de $50 \%$, inicialmente empregado. Os resultados obtidos foram os seguintes:

Tabela 11 - Ciclo de Baixa - Alteração do parâmetro de variabilidade: $35 \%$

\begin{tabular}{|crc|}
\hline Proporção entre contrato/ mercado & Renda Simulada & \% acima do mercado \\
\hline $100-0 \%$ & $1.441,12$ & $-1,609 \%$ \\
\hline $50-50 \%$ & $1.463,22$ & $-0,100 \%$ \\
\hline $30-70 \%$ & $1.472,06$ & $0,504 \%$ \\
\hline $0-100 \%$ & $1.464,68$ & - \\
\hline
\end{tabular}

Fonte: O Autor

Tabela 11 - Ciclo de Alta - Alteração do parâmetro de variabilidade: 35\%

\begin{tabular}{|ccc|}
\hline Proporção entre contrato/ mercado & Renda Simulada & \% acima do mercado \\
\hline $100-0 \%$ & $3.867,56$ & $-5,85 \%$ \\
\hline $50-50 \%$ & $3.987,78$ & $-2,93 \%$ \\
\hline $30-70 \%$ & $4.035,86$ & $-1,76 \%$ \\
\hline $0-100 \%$ & $4.107,99$ & - \\
\hline
\end{tabular}

Fonte: O Autor

A renda simulada para o ciclo de baixa continuou superior mediante a adoção de contratos, ao passo que a lógica se inverteu quando considerado o ciclo de alta. A alteração do parâmetro de variabilidade da FDT implicou a distribuição apresentará um menor desvio-padrão, ou seja, os preços flutuam menos na estimação da distribuição. Os indicadores corroboraram aqueles inicialmente calculados e mostraram que dentro de um cenário com pouca variação dos preços, o mercado ganha forte dominância em relação aos contratos, exceção feita a um período no qual os preços apresentam tendência declinante.

\subsection{Variação do desvio-padrão como elemento contratual}

A terceira análise com alterações marginais nos parâmetros modificou a regra do contrato hipotético, reduzindo e ampliando o multiplicador do desvio-padrão, para respectivamente 0,25 e 2 . Foi assim possível observar o efeito sobre os resultados da simulação levando em conta um contrato mais conservador do ponto de vista do 
comprador (com um intervalo de variação de preços mais restrito) e um contrato menos conservador (com um intervalo maior). Os resultados para o ciclo de baixa foram:

Tabela 12 - Alteração do desvio-padrão para 0,25 desvios-padrão (Ciclo de Baixa)

\begin{tabular}{ccc|} 
Proporção entre contrato/ mercado & Renda Simulada & \% acima do mercado \\
\hline $100-0 \%$ & $1.468,25$ & $0,244 \%$ \\
$-50-50 \%$ & $1.476,79$ & $0,827 \%$ \\
\hline $30-70 \%$ & $1.480,20$ & $1,060 \%$ \\
\hline $0-100 \%$ & $1.464,68$ & - \\
\hline
\end{tabular}

Fonte: O Autor

Tabela 13 - Alteração do desvio-padrão para 2 desvios-padrão (Ciclo de Baixa)

\begin{tabular}{ccc|} 
Proporção entre contrato/ mercado & Renda Simulada & \% acima do mercado \\
\hline $100-0 \%$ & $1.468,87$ & $0,286 \%$ \\
\hline $50-50 \%$ & $1.477,10$ & $0,848 \%$ \\
\hline $30-70 \%$ & $1.480,39$ & $1,072 \%$ \\
\hline $0-100 \%$ & $1.464,68$ & - \\
\hline
\end{tabular}

Fonte: O Autor

A dominância dos contratos sobre o mercado no ciclo de baixa não sofreu alteração. Os indicadores não sofreram variações substanciais entre as duas configurações propostas. Os resultados para o ciclo de alta foram:

Tabela 14 - Alteração do desvio-padrão para 0,25 desvios-padrão (Ciclo de Alta)

\begin{tabular}{|ccc|}
\hline Proporção entre contrato/ mercado & Renda Simulada & \% acima do mercado \\
\hline $100-0 \%$ & $4.234,89$ & $-6,28 \%$ \\
\hline $50-50 \%$ & $4.376,84$ & $-3,14 \%$ \\
\hline $30-70 \%$ & $4.433,62$ & $-1,88 \%$ \\
\hline $0-100 \%$ & $4.518,79$ & - \\
\hline
\end{tabular}

Fonte: O Autor

Tabela 13 - Alteração do desvio padrão para 2 desvios-padrão (Ciclo de Alta)

\begin{tabular}{|ccc|}
\hline Proporção entre contrato/ mercado & Renda Simulada & $\%$ acima do mercado \\
\hline $100-0 \%$ & $4.267,94$ & $-5,55 \%$ \\
\hline $50-50 \%$ & $4.393,36$ & $-2,78 \%$ \\
\hline $30-70 \%$ & $4.443,53$ & $-1,67 \%$ \\
\hline $0-100 \%$ & $4.518,79$ & - \\
\hline
\end{tabular}

Fonte: O Autor 
Os indicadores para o ciclo de alta mostraram que o arranjo institucional que gera maior fluxo de renda é a escolha pelo mercado. A tabela 12 mostra que se o contrato for mais restrito essa superioridade é mais acentuada, pois o percentual da renda acima do mercado é maior do que se comparado com o resultado da tabela 13 , que reflete um contrato menos conservador. 


\section{ANÁLISE DE RESULTADOS}

Ese capítulo avaliará as hipóteses elaboradas no capítulo três com os resultados obtidos de modo a levantar elementos que permitam avaliar a sua aderência à realidade. A primeira hipótese a ser testada visava entender se a escolha do produtor na venda de seu produto (mercado) era a melhor, mais eficiente, sob o ponto de vista da geração de renda, do risco e da segurança institucional. Considerando que a produção de café implica dispêndio de custos iniciais e que a angústia do produtor é a de não recuperar tais gastos, se após a colheita for possível obter algum lucro, essa possibilidade já seria atraente. Essa é a melhor decisão?

Dessa forma, a essa hipótese subscreveu-se outra questão: no longo prazo essa decisão é justificada? Assim foi construído um modelo que simulava a renda do produtor considerando sua atuação no mercado à vista e mediante uma forma transacional alternativa. Criou-se um contrato, calcado numa relação de compromisso de entrega de café de longo prazo. O resultado compreendia transações hipotéticas durante vários anos subsequentes, olhando para o período entre 1996 e 2011.

Os resultados mostraram que a renda gerada por transações via mercado é superior àquela derivada dos contratos. Essa superioridade mostrou-se, porém, marginal. Observando de forma segregada, um ciclo de baixa para o preço do café a superioridade para a escolha pelos contratos toma lugar, ainda que também marginalmente. Em contrapartida, dentro de períodos com movimentos ascendentes de preço, a venda no mercado à vista é aquela a oferecer ganhos mais vistosos ao cafeicultor.

O modelo de simulação apontou, portanto, que para os anos de análise, a renda gerada pela venda no mercado à vista é marginalmente superior àquela gerada pela venda via contratos, considerando também negociações híbridas com percentuais de alocação entre mercado e contratos. O caráter marginal permite inferir que, no longo prazo, essas rendas sejam equivalentes. Como verificar se há eficiência na escolha dos cafeicultores?

Um olhar estrito aos números do modelo de simulação pode apontar uma igualdade entre as formas transacionais ao longo dos anos. Durante um ciclo de alta, a escolha via mercado é superior, enquanto no de baixa, a dominância inverte, de modo que as diferenças entre seus resultados se anulem, desta forma, a hipótese seria refutada. 
Essa alternância de superioridade das formas transacionais, segundo o modelo proposto, estaria associada apenas às variações do preço do café. Certamente, um modelo complexo que envolvesse um maior número de variáveis seria necessário para a obtenção de uma resposta mais complexa. Olhar para outros componentes mantidos como fixos no modelo de simulação, como, por exemplo, a taxa de desconto e as quantidades envolvidas nos contratos seria primordiais.

Assim para contornar esta limitação foram realizadas três analises chamadas de marginalistas, nais quais todos os parâmetros são mantidos fixos, permitindo que uma variável de escolha seja pontualmente alterada. Esse conjunto de testes incluiu alterações nos parâmetros de variabilidade e no multiplicador do desvio-padrão, conforme definido no contrato hipotético. Além disso ao desconto intertemporal do fluxo de renda projetado foi acrescentado um prêmio de risco, de modo a verificar os resultados para um produtor avesso e propenso ao risco.

Esse conjunto de análises corroborou os primeiros resultados apresentados, apresentando indicadores que mostram superioridade mais acentuada dos contratos no ciclo de baixa e do mercado a vista durante o ciclo de alta.

Se no modelo de simulação foram realizadas análises supondo propensão e aversão ao risco, as entrevistas mostraram produtores avessos ao risco, preocupados com a remuneração da sua lavoura de modo minimamente necessário, capaz de permitir o reinício da produção na safra seguinte.

Foi notado nas entrevistas que, sob a visão do produtor, uma transação eficiente é aquela que lhe garanta alguma margem sobre seu custo de produção. De certo, uma relação estável (via contratos) com uma contraparte compradora do café é objeto de desejo do produtor. Mas a essência do almejo dessa estabilidade é a de uma garantia de que o café seja vendido sob um preço acima de seu custo, independente da magnitude dessa diferença. Considerando-se que o cenário no qual isso não ocorre representa o grande risco para essa atividade econômica, o mercado torna-se a forma transacional mais fácil para evitá-lo.

Portanto, no curto prazo, uma transação no mercado à vista que garanta uma margem de lucro sobre o custo unitário da saca de café, pode ser considerada eficiente quanto à geração de renda e a aversão ao risco. No longo prazo, essa hipótese não 
necessariamente é verificada, ainda que essa não seja a orientação predominante para o cafeicultor.

Nesse sentido, a segunda hipótese deveria entender como o produtor relaciona o risco com suas decisões. As entrevistas esclareceram como a percepção de risco afeta as decisões, estratégias e posicionamento do cafeicultor. Os três produtores classificaram a cafeicultura como uma atividade de alto risco e assim pôde ser verificado que a percepção de risco influencia o comportamento do produtor. Os principais fatores de risco apontados foram praticamente idênticos. O preço, o clima, o ambiente institucional e os custos de produção comprometem o desempenho econômico da safra.

Se as condições do clima forem prejudiciais, a safra poderá ser comprometida, pois afetará a estrutura de custos e o preço da saca. Em duas das fazendas visitadas, a indefinição dos custos associados à contratação de mão de obra e o preço final da saca foram mencionados como os grandes elementos de difícil mapeamento. A união dessas variáveis, a margem de custo, representa o fator de risco que influencia a escolha pelo mercado à vista. Primeiro, o produtor necessita sentir-se seguro quanto à existência de uma margem, para então pensar em formas de transação que proporcionem margens de maior magnitude.

Dado isso, a terceira hipótese relacionava o ambiente institucional como fator de risco para a cafeicultura e consequentemente como fator de influência para a decisão dos agentes.

Contratos aos moldes do formato sugerido no processo de simulação despertam o interesse dos cafeicultores, mas existem entraves associados à falta de respaldo dos agentes garantidores do ambiente institucional, ou seja, daqueles que garantiriam o enforcement do acordo. Dessa forma, a reputação, fator mencionado pelos produtores entrevistados, surgiria como determinante para que o estabelecimento dessas relações fosse possível.

Contrapartes compradoras do café que aceitassem a realização de contratos que garantissem um nível de preço durante safras subsequentes deveriam ter grande confiança por parte do mercado. Do contrário, o mercado à vista sobressairia como forma transacional. Portanto, o ambiente institucional gera risco para a existência de relações contratuais de longo prazo, impelindo os cafeicultores a atuar no mercado à 
vista. Fatores associados à reputação e à confiança entre as partes envolvidas numa eventual relação contratual de longo prazo poderiam mitigar esse tipo de risco. 


\section{CONSIDERAÇÕES FINAIS}

Este trabalho procurou unificar a visão de risco com a tendência dos cafeicultores de não estabelecer contratos de longo prazo e optar pela venda de sua produção via mercado spot. Os riscos associados ao comportamento do preço e aos custos de produção impelem a venda no mercado à vista. Ainda que seja reconhecido que os contratos possam mitigar tais riscos, travá-los pode encontrar barreiras associadas à confiabilidade das contrapartes envolvidas. A necessidade de remunerar os custos de produção torna mais atraente a busca pelas transações de mercado. Dessa forma, o pressuposto teórico de mitigação de risco via contratos foi verificado e confirmado pelos agentes, mas isso não implica que essa será a forma de governança a ser escolhida.

Em um ambiente no qual não existe a possibilidade de quebra contratual, os contratos seriam travados em horizontes de tempo extensos. Mas a percepção de que o ambiente institucional não seria suficiente para garantir o cumprimento dos contratos aparece como elemento de intimidação e recrudescimento da escolha por contratos.

Conforme o contato com os produtores do Sul de Minas Gerais seria necessário buscar parceiros, contrapartes compradoras, com reputação e credibilidade capazes de atraí-los nessas relações de longo prazo. Dessa forma, o principal fator de risco para os cafeicultores, a obtenção de uma margem de lucro sobre seu custo de produção poderia ser mitigado.

O modelo de simulação apontou que sob o ponto de vista da geração de renda, essas formas de negociação seriam muito próximas em desempenho. Um modelo mais robusto que pudesse incorporar condições de oferta e demanda pelo café é essencial. A simulação aqui realizada procurava detectar a presença de dominância entre as formas transacionais, observando o comportamento da volatilidade dos preços da saca de café.

Como agenda para estudos futuros, este trabalho abre algumas frentes. Dadas as declarações acerca da relevância dos custos de mão de obra, seria importante investigar e pensar em formas de estimar as funções de custo das lavouras. É pertinente também no prosseguimento da linha deste trabalho, partir para o entendimento do não

surgimento de relações contratuais de longo prazo sob o ponto de vista dos compradores 
do café. É necessário, portanto, relacionar os motivos pelos quais as empresas torrefadoras encontram dificuldades em estabelecer parcerias com os cafeicultores, que conforme mostra este trabalho demandam por tais relações contratuais. 


\section{REFERÊNCIAS BIBLIOGRÁFICAS}

ALLEN, D.; LUECK, D.. The nature of the farm: contracts, risk, and organization in agriculture. Sao Paulo: Mit Press, 2002

BAIRD, B.; OLESEN, H.. Managerial decisions under uncertainty: an introduction to the analysis of decision making. J Wiley: New York, 1989.

BARROS, L. A. B. C.; SILVEIRA, A. M. S. Excesso de confiança, otimismo gerencial e os determinantes da estrutura de capital. Revista Brasileira de Finanças, v.6, n. 3, p.293-334, 2008.

BARZEL, Y. 1997. Economic Analysis of Property Rights. Cambridge University Press.

BARZEL, Y. 2000. Property rights in the firm. In Machesney Eds. Princenton University.

BUSCAGLIA, Edgardo; RATLIFF, William. Law and Economics in Developing Countries. $1^{\text {a }}$ ed. Stanford: Hoover Institution Press.

BAZERMAN, M. H.; NEALE, M. A. Negociando Racionalmente. 2. ed. São Paulo: Atlas, 1998.

BESANKO, D.; DRANOVE, D.; SHANLEY, M.. Economics of strategy. New York: Wiley, 2000. 
BINSWANGER, H.. The measurement of technical biases with many factors of production. American Economic Review, n.10, p.75-90, 1974.

BOGETOFT, P.; OLESEN, H.. Design of production contracts: lessons from theory and agriculture. Copenhagen: Copenhagen Business School Press, 2004.

BUZENITZ, L.; BARNEY, J. Differences between entrepreneurs and managers in large organizations: biases and heuristics in strategic decision-making. Journal of Business Venturing, v.12, p.9-30, 1995.

CHEUNG, S.N.S.. The theory of share tenancy. Chicago: The University Of Chicago Press, 1969.

CLEMEN, R.. Making hard decisions: an introduction to decision analysis. Belmont: Duxbury Press, 1996.

COASE, R.H.. The problem of social cost. Journal of Law and Economics, v.3, p.1-44, out. 1960 .

CORREA, A.. Derivativos agrícolas. São Paulo: Globo, 2005.

CRIVISQUI, E. Presentación de los métodos de clasificación. Programa Presta, ULB, 1999. 
CUADRAS, C. M. Métodos de análisis multivariante. Barcelona: EUNIBAR - Editorial Universitária de Barcelona S. A., 1981.

DAVIS, J.; GOLDBERG, R.. A concept of agribusiness. Cambridge: Harvard University, 1957.

EALES, J.S.; ENGEL, B.K.; HAUSER, R.J.; THOMPSON, S.R. Grain price expectations of Illinois farmers and grain merchandisers. American Journal of Agricultural Economics, Chicago, v. 72, n. 1, p.701-708, March. 1990.

FARINA, E.M.M.Q.; Azevedo, P.F.; Saes, M.S.. Competitividade: mercado, estado e organizações. São Paulo: Singular, 1997.

FERREIRA, C. F.; YU, A. S. O. Todos acima da média: excesso de confiança em profissionais de finanças. Revista de Administração, São Paulo, v.38, n.2, p.101-111, 2003.

GOODWIN, P.; Wright, G.. Decision analysis for management judgment. New York: Wiley, 1998.

JORION, P.. Value at risk. São Paulo: BM\&F, 2003.

JOSKOW, P.. Contract duration and relationship specific investments: empirical evidences from coal markets. American economic review. Pittsburgh, n.10, p.234-179, ago. 1987. 
KAHNEMAN, D.; TVERSKY, A. Prospect Theory: an analysis of decision under risk. Econometrica, v. 47, n. 2, p. 263-291, 1979.

KIDD, J. The utilization of subjective probabilities in production planning. Acta Psicologica, v. 34, p. 338-347, 1970.

KIM, J.; MUELLER, C. W. Factor Analysis - Statistical methods and practical issues. Iowa: University of Iowa, 1978.

KNIGHT, F.. Risk, uncertainty, and profit. Boston: Augustus M Kelley Pubs, 1921.

LICHTENSTEIN, S.; FISCHHOFF, B.; Phillips, L. D. Calibration of probabilities: the state of the art to 1980. In: Kahneman, D.; Slovic, P.; Tversky, A. (eds.). Judgment under uncertainty: heuristics and biases. Cambridge University Press, Cambridge, UK, pp. 306-334, 1982.

LIMPERT, E.; STAHEL, W.; ABBT, M. Log-normal distributions across the sciences: keys and clues. BioScience, Washington, v. 51, n. 5, p. 341-352. 2001.

MARCH, J. G.; SHAPIRA Z. Managerial perspectives on risk and risk taking. Management Science, v. 33, n. 11, p.1404-1418, 1987.

MASTEN, S.. Contractual choice. Working Paper. University of Michigan Law School, n.99-104, ago. 1998.

MOTTA, W.. Derivativos de agronegócios. São Paulo: Saint Paul, 2008. 
NORTH, Douglass C. Institutions. The American Economic Review, vol. 05, n. 01, p. $97-112,1991$.

ODEAN, T. Do Investors Trade Too Much? American Economic Review, v. 89, n. 5, p. 1279-1298, 1999.

OSKAMP, S. Overconfidence in case-study judgements. Journal of Consulting Psychology, v. 29, n. 3, p. 261-265, 1965.

REZENDE, Cristiane Leles. Pacta sunt servanda? Quebra dos contratos de soja verde. 2008. 144p. Tese (Doutorado) - Universidade de São Paulo, São Paulo, 2008.

RUSSO, J.; SCHOEMAKER, P. Managing overconfidence. Sloan Management Review, v. 33, n. 2, p.7-17, 1992.

SAS. SAS/STAT - user's guide. Cary: SAS Institute Inc., 1990.

VARIAN, H.. Microeconomia: princípios básicos. São Paulo: Campus, 2003.

WEINSTEIN, N. Unrealistic optimism about future life events. Journal of Personality and Social Psychology, v. 39, n. 5, p. 806-820, 1980.

WILLIAMSON, O.. The Economic Institutions of Capitalism: Firm, Markets, Relational Contracting. Nova York: The Free Press, 1985. 
WILLIAMSON, O.. The mechanisms of governance. Oxford University Press, Oxford, 1996.

WILLIAMSON, O.; WINTER, S.. The nature of the firm: origins, evolution, and development. Oxford: Oxford University Press, 1993.

ZYLBERSZTAJN, D. Estruturas de Governança e coordenação do agribusiness: uma aplicação da Nova Economia das Instituições. Tese (Livre Docência) - Faculdade de Economia, Administração e Contabilidade. São Paulo: Universidade de São Paulo, 1995.

ZYLBERSZTAJN, D.. Caminhos da agricultura brasileira. São Paulo: Atlas, 2011.

ZYLBERSZTAJN, D.; FARINA, E.M.M.Q.. Strictly coordinated food systems: exploring the limits of the Coasian firm. International Food and Agribusiness Management Review, n.2, p. 249-265, 1999.

ZYLBERSZTAJN, D.; MIELE, M.. Stability of contracts in the Brazilian wine industry: improving quality attributes through chain coordination. Revista da sociedade brasileira de economia e sociologia rural. Brasília, v.43, n.02, p.353-371, 2005.

ZYLBERSZTAJN, D.; NOGUEIRA, A.. Estabilidade e difusão de arranjos verticais de produção: uma contribuição teórica. Economia e sociedade. Campinas, v.11, n.2 (19), p.329-346, jul./dez. 2002. 